\title{
Taking Jinzhou Medical University as an Example to Introduce the Construction and Development of Student Native Instrumental Ensemble in Chinese Campus Culture
}

\author{
${ }^{* 1}$ Siyu Tian, ${ }^{1}$ Yuchen Jiang, ${ }^{1,3}$ Hangqi Liu, ${ }^{2}$ Huibing Tan*
}

${ }^{1}$ Department of social science and art, College of Humanities and Management, Jinzhou Medical University, Jinzhou, Liaoning, 121001, China

${ }^{2}$ Department of Anatomy, School of Basic Medical Sciences, Jinzhou Medical University, 121001, China

${ }^{3}$ Harbin Conservatory of Music, Harbin, Heilongjiang, 150028, China

*Correspondence: Huibing Tan, E-mail: davidtanhb@ foxmail.com; Siyu Tian, E-mail: superqin1988@,foxmail.com. No.40, Section 3, Songpo Road, Linghe District Jinzhou City, Liaoning Province, 12100, P. R. China.

Abstract: Traditional music is gaining more and more attention in higher education in China. As a Chinese music culture, traditional folk music is also a powerful means to strengthen the construction of socialist spiritual civilization, subtly improve students 'aesthetic standards, cultivate sentiment, and promote the development of physical and mental health, and also help to improve the soft power of home country. This article takes the folk music club of Jinzhou Medical University as an example, and discusses its development, construction, management, function, and achievements. A few relevant events are analysis and reviewed. The folk music club was established in 2013, and a total of more than 100 members performed large-scale performances on and off campus. In addition to active campus life and enriching students 'own cultural accomplishments, we believe that medical students' specialty in playing musical instruments will also benefit their future careers. In accordance with the content of the professional courses, we have introduced concepts of context in music therapy and special lectures on music and neuroscience for our students. We hope that the student music club, while inheriting the traditional Chinese music culture, will also enhance its medical practice ability and achieve the goal of comprehensive development and education.

Keywords: Jinzhou Medical University; Native instrumental ensemble, Music club; Chinese traditional music; Club function; Music therapy

\section{CONFLICT OF INTERESTS}

The authors have no conflicts of interest to declare.

\section{Table of contents}

1 Construction process and management of folk music clubs in Jinzhou Medical University

1.1 Feasibility study stage

1.2 The construction phase of the association staff 
1.3 Construction information feedback stage

1.4 The stage of continuous improvement of the operation of the community

2 Functions of Jinzhou Medical University Folk Music Association

2.1 Effectively create a harmonious atmosphere from campus to society

2.2 The ability to enhance aesthetics from individual to the whole school

2.3 The function of enhancing humanistic feelings

3 Main achievements and case analysis of the folk music club of Jinzhou Medical University

3.1 Traditional folk ensemble and solo tracks

3.2 Folk song adapted folk ensemble and solo tracks

3.3 Interludes in Western classic movies and games

3.4 Compilation of ancient style and online platform music

3.5 The combination of the second element and the new folk music

4 Problems and suggestions for folk music club of Jinzhou Medical University

4.1 Issues in the folk music club of Jinzhou Medical University

4.2 Suggestions for the development of folk music clubs in Jinzhou Medical University

5 Orchestration and arrangement of native musical instruments with problems of the using staffs and numbered musical notation

6 Learning from the experience of Western musicians to create Chinese themes of folk music

7 Music club activities and the performance of folk musical instruments benefit from student career as a practicing physician

7.1 Music Healing and Humanistic Care Concept

7.2 Music therapy

7.3 Preliminary practice

7.4 Functional music

8 Insights and summary

Note: This article was originally written in the form of a case study and was prepared to participate in the "National Sixth College Students Art Exhibition". For the special situation, there is an epidemic this year and no specific notice has been received since then. We temporarily decided to rewrite the relevant content. Based on the case analysis of student native instrumental club in our medical university, literature review on the education and inheritance of folk music and musical instruments is conducted with consideration of music therapy. 


\title{
以锦州医科大学为例介绍中国大学校园文化中学生 民乐社团的建设与发展
}

\author{
1 田思宇*, 1 姜禹辰, 1,3 刘航奇, ${ }^{2}$ 谭会兵* \\ 1 人文与管理学院, 2 基础医学院, 锦州医科大学, 锦州, 辽宁省 \\ 3 哈尔滨音乐学院, 哈尔滨, 黑龙江
}

摘 要: 传统音乐在我国高等学校教育中越来越受到重视, 传统民乐作为中 国音乐文化也是加强社会主义精神文明建设, 潜移默化提高学生审美水准、陶冶 情操、促进身心健康发展的有力手段, 也利于提高国家软实力。本文主要以锦州 医科大学民乐社团为例, 从其发展, 建设, 管理, 功能, 成果, 案例几个方面进 行讨论。该民乐社团成立于 2013 年, 共计有百余名成员在校内外进行大型演出。 除了活跃校园生活, 增进学生自身文化修养, 我们认为医学生的乐器演奏特长, 对其今后的职业生涯也有益处。配合专业的课程内容, 我们开办了音乐治疗介绍 和音乐与神经科学的专题讲座。我们希望学生音乐社团在传承中国传统音乐文化 的同时, 也增进其医学执业能力, 实现全面发展育人目标。

关键词: 锦州医科大学;民乐社团;传统音乐;社团功能;音乐治疗

*通讯作者：谭会兵：davidtanhb@foxmail.com，田思宇，E-mail: superqin1988@foxmail.com

近年来, 传统音乐在我国高等学校教育中越来越受到重视, 传统民乐作为 中国音乐文化也是加强社会主义精神文明建设 [1], 潜移默化提高学生道德和审 美水准、陶冶情操、促进身心健康发展的有力手段, 同时也是提高国家软实力的 重要组成部分 $[2,3]$ 。作为医科院校的学生不仅要有精湛的专业技术和优良的文 化素养, 而且要有高尚的道德品质和深厚的人文情怀[4-6]。这也越加证明优秀的 民族音乐社团是在校大学生课余文化生活的重要阵地, 是第一课堂第二课堂的有 益补充, 有其自身的文化特色和存在的价值。我们以我校民乐团为例, 对此进行 交流讨论。

学生的民族乐器才艺有助于活跃学校的校园文化生活。我校历史有 70 多年, 2013 年成立专门的学生社团: “华风夏韵” 民乐队。自建立以来，共计有百余名 成员在校内外进行大型演出, 目前有注册团员 40 余名(表 1)。从中国传统与现代 的融合到中西音乐元素的加入，从经典民族民间音乐与二次元音乐的合并到通俗 与高雅音乐的过渡 [7], 从中国传统经典民乐合奏《赛马》、《十面埋伏》、《金蛇 狂舞》、《彩云追月》等到创新型改编曲目《知否知否应是雪落下的声音》、《 $\mathrm{Bad}$ guy》、《九九八十一》、《权御天下》等乐曲的编排, 我校民乐队也在学校搭建的 素质发展平台上从同学们自身出发, 寻找到最为合适的管理方式, 帮助他们进一 步实现多元发展。组建民乐艺术社团不仅是拓展德育的途径, 也是传承中国传统 音乐文化、实施德育内容和德育目标的方法和措施之一，具有重要意义[8]。

考虑到音乐在普通听众具有的娱乐性，通俗性和平民化演奏，借助民乐团， 合唱团和有关音乐的其他学生社团, 借由我校为医学院校的有利条件, 我们尝试 
在社团活动中加入音乐治疗, 艺术疗愈等概念的介绍。让医学院的学生乐手们, 尝试把业余爱好融合到今后的职业生涯中, 并进一步思考潜在的功能音乐和治疗 音乐发展空间。

\section{1 锦州医科大学民乐社团建设过程与管理}

我校民乐艺术社团的建设思路按照时间可以分为可行性研究、社团人员建 设、信息反馈、运行改进这四个阶段。

\section{1 可行性研究阶段}

这一阶段的主要任务就是对民乐队整体进行具体的描述和规划, 确定整个社 团所需的乐器、设备等必备条件和队员的训练时间的安排、学分的汇总、假条的 设计等内部条件。同时民乐队成员是开放性地面向全校各个专业的学生进行招募, 不同专业的学生聚集在一起会形成一个多元的民乐队建制。在学生处于容易接受 新鲜事物的时期, 他们能够将各种元素吸收并加以融合转换 [8]。同时他们对于音 乐的兴趣, 使得在进行校园学术交流或者音乐活动的时候, 都能够引起学生高度 的关注[9]。这对于校园活动的开展和学生精神素养的提高起到良好的促进作用 [10], 并加强调研形成可行性报告和校内艺术团组织负责人进行研究。

\section{2 社团人员建设阶段}

该阶段主要任务是就已经开展的社团活动进行详细的管理。从“做什么”出 发, 到“怎么做”来进一步发展。从成员们的参与训练情况、每次出勤人数、对练 习曲目的掌握情况到与专业任课老师的排练情况进行调查, 定期指出现行社团的 问题和不足, 到与考勤人员、活动策划人员和校级组织老师了解新的活动情况, 为民乐队及成员确立新机制的需求, 形成一定的报告。

这个阶段是整个社团发展工作的关键。其中主要是民乐队成员的管理与训 练, 也就是说根据社团系统分析所规定的要求, 结合我校的实际情况, 具体设计 实现社团建设。其中在训练过程中, 会积极借鉴中国传统音乐内容, 让校内外新 一代大学生与青年朋友有更多的机会接触中国传统音乐文化, 了解传统音乐与器 乐的鬼米力, 感悟中华沉淀之美。同时, 关照和重视年轻人的音乐趣味 [11, 12], 训练曲目会优先向校内同学及队内成员征集喜爱的流行乐曲, 提升成员们训练积 极性的同时, 让民乐这类传统乐器更易于新青年一代接受。

在社团建设与人员管理中, 主要通过三个层面来完善管理机制。一是校方的 宏观把控, 锦州医科大学民乐社团, 从最初隶属于校团委到如今划分为大学生艺 术团三团五队中的一个重要团队足以证明校方的重视, 从这一点可以看出上层的 领导力更有助于推动优化管理。二是聘任专业教师进行实践教学, 教师作为学校 的中坚力量更像是一个坚固的纽带, 也起到承上启下, 上传下达的作用。三是充 分发挥民乐团里优秀成员骨干成员的示范作用, 笔者认为这一点至关重要, 再多 的文件传达要求也不如学生之间彼此互动与影响来的切实有效, 笔者作为民乐社 团的指导教师, 更是充分认识到其中重要性, 从选举社团负责人到各个乐器声部 负责人, 都本着选择积极正能量, 乐观开朗, 认真负责且专业过硬的同学的原则, 通过整个团队的核心成员, 由点带面影响整个团队。

\section{3 建设信息反馈阶段}

在这个阶段, 主要是通过前期的具体民乐队建设的各项活动和老师与成员间 的训练活动得出运行机制等各方面进行信息的反馈, 对训练成效和演出效果进行 
评价。在保留 “请进来、走出去” 的传统器乐教学优势的基础上, 加强社会交流 实践。吸收其他学校民乐教学优势, 结合古典音乐、流行音乐等等多元化音乐元 素, 在实践中总结经验, 并在实践中找到民乐发展的新思路、新道路。从而建立科 学、完整、优化的民乐训练体系, 培养出一支在各自专业领域发展优秀、在民乐 学习中依旧优异的队伍, 使学生的综合素质得到培养和提高。做到 “润物” 于 “有 声”之中 [13]。这不仅进一步提升成员们的参与度, 还能让每一届民乐队同学增 进对中国传统音乐文化的喜爱, 为下一届的传承与发展提供新的动力。

\section{4 社团运行不断改进阶段}

在这整个民乐队训练活动和演出活动环环相扣的同时, 也需要在社团运行进 入正常化的前提下, 不断的查缺补漏不断的改善。通过了解到的问题着手, 与学 校加强联系与对民乐队的大方向领导, 明确社团建设的任务与具体方针。并从社 团活动制度建设、紧密联系指导教师协助建设、增强队内成员干部建设、抓好民 乐队自身特色建设等四部分出发, 激发民乐队成员的自主探究意识, 充分发挥潜 能, 提高教师与同学们不断创新工作思路、改变活动方式, 提高学生批判继承传 统文化的创新建设精神。

\section{2 锦州医科大学民乐社团的功能[14]}

\section{1 有效营造和谐氛围一一校园到社会}

通过近两年的社团建设不断完善，成员管理体系的不断进步，我校民乐队在 校内外及锦州市社区多处舞台均展现了中国传统音乐文化的魅力。从建国 70 周 年的改编曲目获得校内领导的一致好评到新年晚会、迎新晚会、专场演出等各类 大型展演, 甚至包括进到养老院为老一辈军人进行汇报演出, 医科院校的民乐的 舞台也在慢慢的扩大。也让民乐队的成员们在一次次的演出经验的积累中获得临 场应变的能力与公众舞台的表演勇气。为他们未来的职业能力和社会适应能力也 有一定量的提升。

\section{2 提升审美的能力一一个人到全校师生}

锦州医科大学一直响应国家号召, 提倡校园文化建设, 提高学生的美育德育 修为, 民乐社团则成了不可或缺的一部分。每个团员对于音乐的热爱和执着, 感 动他们周围的同学。校内的每一次演出的曲目, 也必将在一段时间成为同学们身 边, 热议的话题。经典的传统的音乐流传至今, 其作品中的艺术价值不言而喻, 而团员们自己演绎出这样的音乐同时再传播出去, 得到的美育效果是双倍的 [15-17]。

\section{3 提升人文情怀的功能}

作为医科大学的学生, 人文情怀应该是每一位医学生所追求的, 提升自身的 人文情怀音乐是一种不可或缺的手段 $[4,18,19]$ 。每一位走出校门即将成为医生 的学生, 面对着患者面对着死亡, 更要用一颗敬畏之心来对待, 相信他们走出校 园, 面对每一次重大选择, 面对每一次突如其来的疫情, 都有一颗强大的内心和 深厚的人文积淀去面对困难，做到迎难而上做最美的逆行者。例如 2020 年 1 月 武汉爆发的新型冠状病毒肺炎, 学生由于延迟开学纷纷在家拿起手中的乐器, 利 用自媒体发布一些正能量的音乐, 为武汉加油, 为自己奋斗在一线的老师加油, 
为中国加油, 用音乐的力量感染自己与他人, 万众一心攻克疫情。最近, 本文作 者动员 600 多名学生, 组织云端同唱, 选择了一首难度适中的优秀抗疫合唱歌曲 （由央视文艺节目中心制作的）《你安好，我无恙》[20,21]。

\section{3 锦州医科大学民乐社团主要成果及案例分析}

本乐团指导教师从事一定的原创工作，比如田思宇创作了民乐合奏《陕北 情》, 就是用五线谱打谱(链接补充图 1, supplementary material)。用于锦州医科 大学民乐社团演出曲目, 其主要成果按曲目的内容可分为五类 (表 3 , 附录 1)。

\section{1 传统类民乐合奏与独奏曲目}

排练该类型曲目的同学笔者在分配学生时多为高年级的学生, 由于他们经过 前期的磨合与训练, 把音乐不仅仅只看为兴趣爱好和上台表演的途径, 所以更能 沉得下心, 理解传统音乐内涵及作品中的艺术价值。学生们将知识与实际应用相 结合, 从而使他们在校期间得到专业以外的锻炼, 同时提高自己的核心竞争力。 一方面让传统音乐以大众的方式得以传播和接受; 另一方面利用器乐合奏的形式, 增强学生的想象力与创造力 $[22,23]$ 。

曲目成功案例《春江花月夜》、《步步高》、《彩云追月》、《赛马》、《十面埋伏》 《渔舟唱晚》、《金蛇狂舞》、《梁祝》等, 这一类曲目有规范的总谱, 相对排练比 较正规。

\section{2 民歌改编类民乐合奏与独奏曲目}

排练该类型曲目的同学笔者安排大多为大一的新生和部分程度一般的高年 级的学生。曲目本身旋律简单, 需要有一些即兴的演奏法加入, 例如会让琵琶做 单音的长轮, 古筝的大刮奏, 竹笛的花舌, 来填充一些和声的空白。曲目成功案 例为《沂蒙颂》、《线花》、《在水一方》、《红梅赞》、《九儿》。这类曲目没有规范 的总谱, 通常只有一条旋律, 在排练过程中, 也是笔者和学生共同完成编曲。

\section{3 西方经典电影及游戏中的插曲}

排练该类型曲目, 笔者主要考虑到一些男生受众团体, 他们本身是由于一些 BGM 而爱上自己的乐器, 这类同学常常会自己探索一些由西方管弦改编到民乐 的音乐元素。曲目本身和民乐相关不大, 所以在技巧的练习也是一个很大的突破, 由于西方的十二平均律适用于键盘, 而在琵琶和二胡的换把练习就是一个很大的 挑战, 古筝也在转调上成了很大的一个弊端, 通常, 运用两把古筝, 调成相应的 调式, 而笙, 则是一个很好地伴奏乐器。曲目成功案例《Let's play again》、

《Victory》、《加勒比海盗》、《Phoenix》等。在排练该类型曲目中, 由于民乐没 有低音声部, 通常会找到一些伴奏的音频来支撑音乐的平衡, 因此, 民乐的即兴 成分较大。

\section{4 古风及网络平台音乐的编创}

排练该类型曲目同学, 笔者通常会选择刚入学的新生。因为刚入校的新生, 用他们最感兴趣的音乐就可以快速的培养出他们的兴趣, 该类曲目也常常是各大 自媒体平台的“神曲”, 由于传唱度高, 在一些迎新晚会的舞台上, 深受喜爱。成 功曲目案例《芒种》《Bad guy》《广寒宫》《大碗宽面》《火红的萨日朗》《斗地主 背景》《探清水河》《出山》等。该类曲目基本是一些简单的五声调式, 旋律简单 节奏鲜明, 有相应的伴奏, 演出效果良好。通过此类音乐可以快速的让一些不了 
解民乐的同学, 快速加强对民乐的兴趣, 进而再欣赏经典的音乐达到循序渐进的 音乐欣赏, 起到了初步的普及性美育教育, 对于介绍基本的乐理和乐器法讲解也 是一个有效的途径。

\section{5 二次元与新民乐的结合}

该类曲目主要依托网络哔哩哔哩平台实行实践教学，近年来，由于学生的年 纪趋近于零零后, 对于音乐元素的爱好也承现出多元化 $[11,12]$, 很多同学对于 动漫的话题讨论非常热烈, 而动漫周边文化, 例如二次元音乐与新民乐相结合也 是锦州医科大学民乐社进行探讨的话题之一, 笔者利用哔哩哔哩平台和一些其他 自媒体平台, 组织学生观看知名 up 主“团团子” (琵琶) “小二梦” (琵琶) “陆二 胡”（二胡）“墨韵 Moyun”（古筝）等进行新民乐改编教学，同一首音乐经不同 up 主改编后，音乐风格甚至音乐传递内容的方向都有可能发生变化，以琵琶为 例, 通过不同技巧的运用, 快速弹挑, 长轮, 扫, 拂, 凤点头都可以打破原有音 乐所表达的含义, 而推, 拉, 吟, 揉, 顿音泛音的大量加入可以使音乐变得更加 梦幻空灵, 从而改变原曲的基本风格, 由抒情转向悲壮或平淡转向摇滚都是可以 做到的。曲目成功案例《九九八十一》《新九九八十一》《权御天下》等。

\section{4 锦州医科大学民乐社团存在的问题与建议}

\section{1 锦州医科大学民乐社团存在的问题}

锦州医科大学民乐社团虽发展的蒸蒸日上，但也存在着一些结构性的问题， 如民乐成员编制不全，招生不利，乐器不全，维修问题等。尤为突出的是，民乐 社团现主要以实践教学为主, 课时设定与教学内容不能达到理论与实践相辅相 成, 由于学校取消线下的音乐理论课, 导致很多队员在音乐理论方面有所欠缺。 乐理, 视唱练耳, 中西方音乐史, 音乐鉴赏等等这些本该掌握的理论知识学生不 能在课上进行学习, 基本是教师利用课下时间通过网络平台给学生适当的补习, 致使在演奏过程中缺乏理论的支撑常常事倍功半。香港音乐教育研究指出音乐老 师和乐器指导教师对学生的音乐知识教育起到 30-70\%作用[24]。另外, 由于医学 院校专业课繁重, 往往到了大三, 大四, 大五的学生, 因为课业的要求退团, 导 致阶段性时间人员流失过多，做不到真正的老带新[25]。

\section{2 锦州医科大学民乐社团发展建议}

对于民乐编制不全缺少乐器方面, 建议通过多部门多渠道线上线下进行招 募, 大学生艺术团管理部门也需要加大对于乐器的采购和维修的经费投入（表 2)。对于理论与实践不平衡方面, 建议全校增开线下的音乐通识课, 对于美育教 育不应只停留在肤浅的表层, 医学生对于增加自己的音乐人文修养也不仅仅是民 乐社的同学应该重视的, 而是落实到全校每一位学生身上。对于民乐排练时间上 冲突的高年级学生, 建议实行弹性管理, 往往高年级学生对于音乐的热爱不仅仅 是为了修满学分, 而是真正的热爱民乐, 对于此类同学应该实行弹性练习弹性管 理，让更多热爱音乐热爱舞台的同学有机会实现自己的音乐梦。

\section{5 民族乐器配器和五线谱和简谱使用存在的问题}

民族乐团低音声部乐器仍然在引用大提琴、低音提琴等。我们民乐团的现有 乐器缺乏低音演奏乐器, 使得器乐合奏和声效果有一定缺陷, 有时乐团引入电子 合成乐器加入低音改善和声效果。民族乐器的多声部演奏也存在问题, 比如二胡 
很难演奏和声音乐。另外民间乐器的音域也相对西洋乐器, 也是有一定限制。比 如对于古筝有研究不断探索, 希望改进音色和音域[26]。我们今后期待应用钢琴 解决部分低音和声问题。即使学校资源有限，学校有关部门也应该关注民乐队， 增加低音乐器方面, 我们需要经费增添低音乐器。国内的民族乐器有很多成功的 民乐器和钢琴合奏的作品, 具体到我们乐团, 我们也需要自己编曲, 应用钢琴作 为伴奏和声效果。

民乐乐谱过多依重简谱, 应该逐步向西洋乐器看齐, 统一出版使用五线谱。 古代历史上，民乐谱是坚排版的工尺谱[27]，横排的中国乐谱记谱见图 1, 完全 不同于西方[28-30]。现在我们基本看不到中国的记谱方法。当代相当一部分中国 人音乐记谱采用简谱 (附录 1)。据说法国巴黎的理论家(theorist)或称为修士[31] Jean-Jacques Souhaitty（BC1650-?）为了对民众和教民教唱赞美诗，而应用 1-7 数字发明简谱记谱方法[32]。阐述简谱的发展和在中国的应用, 台湾有比较系统 的研究[31]。据称我们的简谱有可能是从日本传到中国的[31], 某种层面上, 我 们的一些音乐教育师从日本。民乐和民歌使用简谱, 一直影响民乐的乐器创作, 虽然简谱是西方人发明的，目前，音乐教育还是五线谱更利于阅读和交流，比如

“渔舟唱晚” 的五线谱比较直观阅读[26]。有报导, 早期的美国华人, 虽然使用 简谱(Based on the moveable "do," jian- pu employs numbers to designate pitches), 但 是合唱音乐就是选用西方的记谱模式(Chinese choral music is based on Western models)[33]。学校规定, 民乐器的演出要以民乐合奏的形式参加演出。编曲, 简 谱对于研究和国际交流, 给目前一些五线谱读谱的人带来一定的困惑, 作为中国 人单一阅读简谱, 也影响用五线谱进行交流和创作，甚至可能会影响民族音乐的 国际推广。我们中国人更应该, 也首先做到简谱和五线谱通识 [34, 35], 而我们 现代多数人倾向于学习五线谱更重要。我们希望民乐古谱除了翻译为简谱, 也应 该有更实用的五线谱作品。国外的教学实践说明, 即使从来没有学习过乐谱 20 岁左右的高校学生, 经过短期课程讲座也能过达成应有的教学效果, 促使部分学 生继续要求学习音乐知识, 并有学生要求进一步学习钢琴课[36]。打谱软件还在 开发用于小学的音乐教学功能[37], 而我们学生经常为打谱遇到困难。

很多民乐旋律来自网络，有些是民歌，如前所述，网络谱子很多时候需要改 编, 这就涉及软件问题, 民乐在有些软件中没有民乐注释和插件, 回放就很困难, 之前的 Finale 2012 就不支持中文打印。打谱软件使用中外作曲家可能使用的观 点有所不同[38], 目前有很多应用简谱打谱软件, 以及为民乐使用的软件[38], 以及五线谱和简谱混编软件编辑研究[39]。

借鉴西方音乐家创作中国主题的中国民乐经验

就如我们开始提到的, 传统音乐和传统民乐作为中国音乐文化也是加强社会 主义精神文明建设的需要, 利于提高国家软实力。即使改编乐曲, 对于作曲家和 乐器演奏也是要有境界的追求。在网络和开放的时代, 作品可以在网络中和网络 媒体中传播。以我们现有的知识, 认为最早的中西方乐器融合交响协奏曲, 是 1936 年由俄罗斯作曲家 Avshalomov 创作和演出的[The Concerto in G Major Upon Chinese Themes and Rhythms for Piano and Orchestra by Russian-Jewish composer Aaron Avshalomov (1894-1965)][40, 41]。当时演出有 14 位中国民乐演奏家参加 了当时的上海交响乐团演出 [41]。Avshalomov 在他的作品中，运用的中国主题， 有二胡独奏乐段, 可能是当时的二胡音量相对较小, 即使其他中国民乐器演奏, 交响乐团和钢琴也需要控制一定的演奏力度[41]。在国外, 中国乐器和民乐, 既 有交响乐团建制的音乐创作，也有小乐队形式创作作品[42]，当然中国民乐也可 
以西洋独奏乐器配器伴奏[34]。在 1960s, 中国有一些作品, 比如《长征组歌》 [43]和革命现代京剧样板戏 [44], 乐队还是配置的一些民族乐器。

如上所述，我们如果探讨 “民乐在医学类高校的传承和发展”，普通院校的 学生的民乐演出实践虽然不能与专业演职员相提并论, 民族音乐的传承和传播需 要广泛的群众基础。我校的民乐队有 40 人左右, 目前, 全国高等学校共计 2956 所（普通高等学校 2688 所） [45], 高等院校学生可以成为民乐的重要基础部分, 高校民乐团成员仍然是民族音乐的践行者。民乐原创性工作比较富有挑战性, 目 前多数作品还是对乐谱进行改编, 有些是把民歌改编为器乐作品[35]。我们部分 成员也从事音乐的原创工作，今后有待专研本民族的音乐，在民族音乐基础上进 行原创, 也可以移植民族音乐与西洋音乐融合, 比如民乐独奏作品中采用钢琴伴 奏。民乐队学生大数具有一定的独奏能力, 合奏会丰富演奏体验, 我们认为民乐 团的经历, 可以帮助他们更进一步地加深理解音乐。本文的作者同时关注民族音 乐发展和民族性音乐及其学术的探讨 [43, 46-48]。

目前, 日本的音乐教学从小学开始完全是按照西方音乐来进行的, 而不是以 日本音乐为基础[49]。这篇文章的题目是: “日本: 音乐作为道德教育的工具吗? ” 在中国香港, 音乐课程设置也不鼓励古典音乐或严肃音乐 [50]。我们注意到早在 1960s 年代, 美国大学的民乐学生团体就相当活跃, 他们发行自己的唱片 [51], 可以和民间民乐音乐家形成一定竞争，形成一定地域和地理影响[52]。1930s-60s 年代的美国, 有共产主义的老左翼的运动（communist-led the Old Left）影响到 民乐 $[53,54]$ 。我国香港的音乐教育和理解视音乐具有社会政治结构(sociopolitical construction), 并且不同于内地的音乐教育 [50]。文革期间, 钢琴伴奏红灯记, 就 使得钢琴这件西洋乐器成为 “高贵的乐器” [50]。革命样板戏用交响乐队伴奏, 同意也成就了西洋乐器[44]。改革开放, 中国的音乐教育[55]和校园音乐呈现更 为广泛文化交流和多元化[56]。我校学生的校园民谣创作也是应运而生, 校园学 生的音乐社团和活动也是多元化的。

西方音乐很早就介绍到中国, 但是开始接受西方音乐教育的时间中国可能晚 于日本, 如今中国的中产阶级, 更倾向于让子女学习钢琴等西方乐器[57]。在中 国，音乐教育为了艺术修养，当然音乐是为劳动者为社会-政治的服务 [58], 也有 多层次的意义, 进行国内外文化交流以及具有社会和政治的辩证关系[1]。《红色 狂想曲：西方古典音乐在中国》一书认为西方古典音乐已经融入中国, 至少在某 些方面赢得更多的听众[44]。交响乐样板戏有些古典音乐演奏家和作曲家已经成 为当今著名音乐家, 中国民乐还没有取得对等的成功。古典音乐有贝多芬成为中 国人的偶像[59], 还有巴赫, 维瓦尔第, 亨德尔, 海顿, 莫扎特, 舒伯特, 门德 尔松, 古诺, 舒曼, 勃拉姆斯, 比才, 肖邦, 柴可夫斯基, 德彪西, 威尔第, 拉 威尔, 李斯特, 瓦格纳, 德沃夏克, 拉赫玛尼诺夫, 马勒, 斯特拉文斯基等, 而 且他们个人创作的曲目也很巨量的, 浩如烟海, 还有很多指挥, 歌唱家和演奏家 灿若繁星。一种乐器, 民乐要想传承和发展, 需要有作品支持, 有作曲家, 演奏 家，歌唱家和指挥等音乐家贡献，好的音乐家集作曲，演奏和指挥于一身。民乐 和古典音乐比较, 和是偏向通俗音乐范畴[60]。无论西方音乐影响有多大, 民乐 仍然是文化基础[61], 即使德国也需要民乐 $[60,62,63]$, 这也是民乐需要支持的 原因 [64]。目前民乐有单一无伴奏演奏逐渐有西化的编曲和配器, 有概念和形式 的变化 $[65,66]$, 包括创作形式的钢琴伴奏, 电声伴奏。由此近年来出现 “新民 乐” 的提法[67, 68]。“女子十二乐坊” 体现了民乐演奏的新时尚[69]。“女子十二 乐坊” 的出现非常轰动和时尚。由于运作过程有日本参与, 因此, 女子十二乐坊 被认为是日本制造(made in Japan)[70]。该作者以女子十二乐坊和日本的鼓童做中 
国传统音乐和日本传统音乐对比研究, 我们发现论文原来的提供的女子十二乐坊 官方网站 http://www.12girls.org/english/yfsj.asp 已经不复存在，而日本的鼓童乐 队 [71]官方网站还是可以访问：http://www.kodo.or.jp/general/history_en.html。女 子十二乐坊 2001 年 6 月在北京成立, 而日本的鼓童乐队追溯到 1980s 年代的日 本太鼓队 (taiko drumming troupe, Kodo) ，其历史大概早于女子十二乐坊十几年。 继而, ViVA-Girls 雅乐团 2009 年 11 月成立, 由 12 位专业院校民乐演奏家们组 成[72]。

\section{7 音乐社团活动和民族乐器乐演奏才艺益于其执业医师生涯}

\section{1 音乐疗愈与人文关爱理念}

我们曾经尝试探讨 “民乐在医学类高校的传承和发展”, 如何才能启动这类 题目? 我们认为音乐的在医学中实际应用也是一种思路。如上所述, 我们的学生 在这次新冠疫情中, 运用乐器演奏积极参与抗击疫情, 但是对于音乐的医学治疗 方面, 我们希望同学们有更明确的认识。接下来的叙述, 主要是让参加民乐演奏 社团的医学生接受音乐治疗的理念 [5]。普遍认为, 音乐治疗 [73]历史, 理论和实 践源于西方。我们发现有些西方学者在开始介绍音乐治疗的时候, 引用一个中国 浐语: “Music comes from the heart of the human being. When emotions are born, they are expressed by sounds and when sounds are born they give birth to music" [74]。除了音乐盲外[75], 音乐对于大都数人来说, 是与生俱来的天性[76-78]。 目前，通识的大众化的维基百科英文的音乐治疗定义： “Music therapy is an evidence-based clinical use of musical interventions to improve clients' quality of life. Music therapists use music and its many facets- physical, emotional, mental, social, aesthetic, and spiritual- to help clients improve their health in cognitive, motor, emotional, communicative, social, sensory, and educational domains by using both active and receptive music experiences. These experiences include improvisation, re-creation, composition, receptive methods, and discussion of music”。(直译为: 音 乐疗法是一种基于证据的音乐干预临床应用，旨在改善客户的生活质量。音乐 治疗师利用音乐及其许多方面 (身体, 情感, 心理, 社会, 美学和精神), 通过 主动和接受音乐体验, 来帮助客户改善认知, 运动, 情感, 交际, 社交, 感官和 教育领域的健康状况。这些经历包括即兴创作, 重新创作, 创作, 接受方法和音 乐讨论)。音乐治疗更多理论的定义[79]，有很多文献注释[79-86]。

\section{2 音乐治疗}

音乐治疗对轻度老年痴呆（Alzheimer's disease） [87,88], 痴呆（dementia） [89], 帕金森[90]和老年认知障碍[91]有一定疗效，甚至对较重的老年痴呆患者, 音乐治疗也会有改善症状[92], 音乐治疗可以用于以下病症或状况: 抑郁[93-95], 包括癌症患者的抑郁 [96], 焦虑 [97, 98]（包括部分心脏病患者焦虑 [99]）, 辅助戒 毒[100]或药物成瘾[101], 某些精神病[102-105], 对于这些患者更重要的是音乐 治疗没有副作用 [105]，儿童孤独症[106-109]（包括严重的患者[110]），儿童感觉 统合失调 [111], 部分脑神经认知损伤修复 [112-115], 减轻手术后疼痛[116], 部 分一些运动康复 $[117,118]$, 改善调整病人精神状态[119-121], 剧烈癌痛[122, 123], 或者姑息治疗 $[121,124,125]$, 临终关怀[126-129]。有些会乐器演奏, 特别 是键盘或吉他, 民乐也是可以应用到音乐治疗上，医学生同学是可以报考音乐治 疗师的。对某些科室是需要的, 北京某工作室音乐治疗预约要等几个月。一个合 
格的医生, 如果具备乐器演奏能力, 又学习了音乐治疗知识, 利于请音乐治疗师 会诊开对应处方, 帮助针对需要音乐治疗的患者就可以进行实施相关的联合医治 方案, 利于和病人互动和观察疗效。Davis 等著称音乐治疗的理论和实践“provides a comprehensive overview of the practice of music therapy for the 21 st century. It looks at where we have been, where we are today, and where we might be in the future" [82]。

\section{3 探索与尝试}

我们认为医学院的学生音乐社团可以成为音乐治疗的一个桥梁。我校民乐社 团的学生演奏能力和水平多数是经过考级认证的, 尚未考级的学生, 其乐器演奏 也是比较优秀, 所有学生都具有一定的独奏能力。他们应该更容易理解和学习音 乐治疗(图 2)。在锦州医科大学, 我们为参加神经科学科学研究的本科生和运动 康复医学专业以及附属医院的医护人员, 介绍音乐与神经科学的知识 [130], 我 们做过 “音乐与脑” 等讲座和读书会 (journal club)。仅仅在学生社团活动, 并 不能形成 “音乐治疗” 专业建设, 结合医学院的职业特点, 引导学生关注音乐治 疗, 介绍功能音乐。对民乐团和其他音乐社团, 比如我校合唱团及其钢琴部, 这 些音乐 “特长生”, 可以建立课外论坛, 现在提倡个性发展, 音乐治疗对于某些 学生老师可能有职业的导向作用。医学院音乐 “特长生” 专业涵盖较广, 即使是 医学专业的在校生, 未来不一定都是做临床医生。音乐本身的功能和音乐演奏, 还是会为医学在校生提供一个个性和特长发挥平台, 未来不见得人人成为音乐治 疗师。目前我国音乐治疗师注册, 可以接受医学生通过音乐治疗培训班途径, 成 为音乐治疗师。我校音乐社团本科学生, 选择音乐治疗和音乐心理专业, 报考相 关专业研究生。

我们指导教师本身也需要进一步学习和充实有关知识, 目前本着教学相长的 想法, 本文对此进行理论探讨, 并在未来的社团实践中, 与学生共同扩展音乐功 能知识。必要时, 根据实际情况, 可以尝试 “请进来, 走出去” 的办法, 在保证 学生主修课程前提下, 请外界专家办讲座, 让学生在一定的成熟条件下, 做志愿 者, 层问社区老人院。比较有挑战性的实践是进入临床实践。我们的有些临床科 室, 比如肿瘤科有医患交流群和医患关爱社区和临终关怀等活动。鉴于师资问题, 我们不能开始专业, 未来可以设想开办选修课, 真正进入课程建设, 执业更需要 一定的时间和管理规范。相关的音乐治疗师和注册问题中外管理也有具体规定 [131，132]。民乐社团建设我们为学生引入音乐治疗理念 [5], 探索思考改进医治 手段, 注重精神心理作用, 完善增进医患关系, 强化医学人文关怀意识 [6]。音 乐本身也具有辅助增进医术作用 $[133 ， 134]$, 音乐治疗本身也是以文化为中心的 [84, 135], 中国民乐器对很多中国人来说, 相对西洋乐器, 更贴近他们的精神和 心理。在此我们想引用一个书名和一个注释: “Music therapy: An art beyond words, it has extended into areas of general medicine, mainstream education and community practice" [81]。

\section{4 功能音乐(functional music)}

音乐对人们的生活和精神有巨大的影响 [133，136]。在古典音乐和通俗音乐 中, 派生出功能音乐 (图 3)。功能音乐与音乐治疗有一定程度的区别, 其作用还 可应用于家庭, 工作和公共场合等[137]。部分概念和应用, 与音乐治疗相互融 合 [138, 139]。功能音乐更多是生理上给人带来快乐 [139], 消除疲劳 [140], 缓 解工厂工作时的枯燥单调 [141], 提高制造业工作效率 [142, 143] 和改善体育运 
动引起的疲劳 $[144,145]$ 。音乐治疗的音乐是针对病人病症, 在医患关系前提下, 由音乐治疗师主导, 通过实时演奏乐器和/或歌唱, 和病人或顾客互动 [146], 其 音乐有即兴演奏特征。功能音乐可以是通过播音设备播放 [143], 音乐内容可以 来源于广播, 可以是商品化定制唱片等媒质, 音乐的聆听者相当场合是面对正常 人, 或者说是一种环境场合需要的音乐气氛需要的音乐, 当然功能音乐也可以是 实时演奏或歌唱的音乐。在公共场合和工作环境操作功能音乐不需要认证, 甚至 不需要有乐器演奏和或演唱技能。音乐治疗师需要专业培训, 要有乐器演奏 [147] 和或演唱能力 $[148,149]$, 更严格地序言专业学位 $[73]$, 从事音乐治疗需要专业 认证, 例如美国认证起点是需要专业学士学位 $[73]$ 。实施音乐治疗, 需要治疗音 乐处方 [150], 简单的情绪调节, 由于年龄的差别, 音乐处方也会根据时代因人 而异 [151]。功能音乐和治疗音乐实施, 更为重要的事, 音乐治疗涉及医疗保险 是否报销问题。台湾地区，音乐治疗不纳入医疗保险 [152]。美国，音乐治疗可 以将纳入医疗保险 [153-155], 但是临终关怀的音乐治疗, 由于属于奢侈消费, 保险就可能不纳保, 有待体问题具体对待 [156]。日本对老年人的神经退行性变 等疾病有保险 $[157]$ 。

功能音乐和治疗音乐可以有一定理解上和应用中形成交叉。比如, 从治疗理 论出发, 注重公共场合和社区为基础的音乐活动, 公益性地组织一些无家可归的 男子, 开展业余演唱, 其目的是促进音乐文化和改善生活质量[158]。显然，有 音乐演奏和或演唱能力的医学能过更好的介入音乐治疗。

\section{8 感悟与总结}

经过两年民乐社团建设的探索和实践，我校民乐社团建设按照整体规划一 致, 基础开拓创新的原则, 培育和造就符合新青年学生和社会需求的 “优秀学生 社团” 组织。在通过开展一系列愉悦身心，陶冶情操、锻炼能力、提高职业素养 的民乐类活动的同时, 使得我校学生素质教育得到不断提高, 传统音乐文化吸收 不断增强, 同时也争取打造出一个品牌团队。

最近, 我国教育部等 6 部门研究重启第二学位[159]。医学生学习和掌握音 乐治疗, 就应运而生了应用性音乐, 功能音乐。美国新的音乐治疗师注册规定, 要求音乐治疗师有专业学位[73], 我们构想一个新的音乐构成模式(图 3)。

在对民乐社团的学生管理建设过程中发现, 优秀的社团活动不仅为学生提供 展示自我的舞台, 让他们的艺术修养不断提高。同时也让学生的兴趣爱好普遍得 以满足, 其个性特长也得以充分发挥。可见优秀明晰的管理体制为把学生的兴趣 爱好向专业技术特长的转变也奠定了良好的基础。由于民乐器在低音区配器方便 的不足, 我们认为钢琴应该成为民乐器的常见合奏乐器(图 2)。

当前, 多重教育的蓬勃发展, 为加强专业性较强的学校社团建设创造了良好 的条件。我校民乐社团的这种新民乐的发展形式也不单单依靠传统民乐，它有自 己的内容, 自己的思想。在新旧民乐融合的发展过程中, 既是对传统民乐的包容, 更是以传统民乐为蓝本，对其再加工，再创作[160]。医学院应该重视学生音乐社 团的建设, 鼓励有音乐特长的学生报考医学院, 在资金和教师人员配置上予以加 强。民乐社团在秉承传承中国传统音乐文化的同时更应该积极行动起来, 积极创 新, 努力探索, 推动学生社团建设更上一个新台阶, 促进学校育人目标的实现。

注释: 本文最初以案例分析形式撰文, 准备参加《全国第六届大学生艺术展演》, 今年出现疫情, 目前没有收到具体通知, 我们临时决定将有关内容重新撰写编辑。 
以医学院校学生社团为案例分析上, 对民族音乐和民族乐器教育和传承进行文献 讨论。

\section{利益冲突声明：本文没有利益冲突。}

\section{参考文献:}

[1] W.-C. Ho, China: A socio-political perspective on the introduction and development of school music, The origins and foundations of music education: International perspectives, DOI (2017) 240-255.

[2] J.A. Millward, Uyghur art music and the ambiguities of Chinese silk roadism in Xinjiang, The Silk Road Journal, 3 (2005).

[3] W.-W. Law, W.-C. Ho, Music education in China: In search of social harmony and Chinese nationalism, British Journal of Music Education, 28 (2011) 371-388.

[4] H. Shoemark, Music therapy as an exercise in humanity, Australian Journal of Music Therapy, 20 (2009) 31.

[5] B. Stige, On a notion of participation in music therapy, Nordic Journal of Music Therapy, 15 (2006) 121-138.

[6] L. McLellan, E. McLachlan, L. Perkins, T. Dornan, Music and health. Phenomenological investigation of a medical humanity, Advances in Health Sciences Education, 18 (2013) 167-179.

[7] W.-C. Ho, Popular music, cultural politics and music education in China, Taylor \& Francis2016.

[8] W.-C. Ho, W.-W. Law, The cultural politics of introducing popular music into China's music education, Popular Music and Society, 35 (2012) 399-425.

[9] 田硕硕，浅论高校民乐团与校园音乐文化建设，文教资料, 28 (2015) 64-65.

[10] H.P. Weld, An experimental study of musical enjoyment, The American Journal of Psychology, 23 (1912) 245-308.

[11] H. Huang, Voices from Chinese rock, past and present tense: social commentary and construction of identity in Yaogun Yinyue, from Tiananmen to the present, Popular Music \& Society, 26 (2003) 183-202.

[12] T. Hsieh, Jazz meets east: Cultural dimensions of asynchronous jazz music development in modern China, Oberlin College, 2012.

[13] 周杰, 浅谈高校教育中开设民乐课程的必要性, 广西教育学院学报, 05 (2007) 77-78.

[14] 何可人，普通高校民乐团在校园文化建设中的功能与未来发展的思考，大众文艺，05 (2019) 207.

[15] I. Cheremisova, Music and development of creative personality within higher education environment. Aesthetic and semiotic approach, European Journal of Multidisciplinary Studies, 2 (2017) 78-87.

[16] K. Swanwick, A basis for music education, Routledge2002.

[17] L.B. Meyer, Explaining music: Essays and explorations, Univ of California Press1973.

[18] A. Storr, Music and the Mind, Simon and Schuster2015.

[19] B. Abrams, Understanding music as a temporal-aesthetic way of being: Implications for a general theory of music therapy, The Arts in Psychotherapy, 38 (2011) 114-119.

[20] 文化艺术中心, 锦州医科大学教师教学发展中心, 校园时讯 | 歌声汇聚力量 美育涵养人 心——文化与艺术素质教育平台云端同唱一首歌活动纪实， 
https://mp.weixin.qq.com/s/B7kGxX0nSWhyv3dTPgtHxA, DOI (2020, May 28).

[21] 田思宇, 关宁宁, 锦州医大 600 余大学生云端同唱一首歌, 锦州晚报, http://www.1m3d.com/thread-612928-1-1.html (2020 Jun 5).

[22] 岳晓金金，浅谈高校民乐团的多元发展，戏剧之家, 11 (2017) 246.

[23] R.K. Sawyer, Group creativity: Music, theater, collaboration, Psychology Press2014.

[24] W.C. Ho, Musical behaviour of young Hong Kong students, Educational Research Journal, 17 (2002) 197-217.

[25] 赵楠, 高校民乐团创新发展途径和方法, 黑龙江科学, 8(09) (2017) 60-61.

[26] J. SHI, Extending the sound of the guzheng, University of York, 2014.

[27] G. Chen, W. Zhang, Chinese Gong-Che Notation Musical Score Image Segmentation Based on an Anticlockwise Rotation Extension Algorithm, 2009 International Conference on Computational Intelligence and Software Engineering, 2009, pp. 1-4.

[28] C. Yingshi, Ancient Chinese music notation, Anuario Musical, 44 (1989) 239.

[29] G.-F. Chen, J.-S. Sheu, An optical music recognition system for traditional Chinese Kunqu Opera scores written in Gong-Che Notation, EURASIP Journal on Audio, Speech, and Music Processing, 2014 (2014) 7.

[30] J.A. Van Aalst, Chinese music, Cambridge University Press2012.

[31] 李彥勳, 簡譜之發展與其使用於台灣音樂教育之調查, DOI (2005).

[32] A. Cohen, Souhaitty, Jean-Jacques, Oxford University Press, 2001.

[33] A.R. Mazur, Music in New York City's Chinese Community, New York Folklore, 14 (1988) 89.

[34] L. Jiang, The Interaction of Cello and Chinese Traditional Music, University of Kansas, 2016.

[35] S. Deng, Conversations, DOI (2013).

[36] S.-L. Tan, E.M. Wakefield, P.W. Jeffries, Musically untrained college students' interpretations of musical notation: sound, silence, loudness, duration, and temporal order, Psychology of Music, 37 (2009) 5-24.

[37] J. Julia, P.D. Iswara, S. Gunara, T. Supriyadi, Developing Songs for Elementary School Students with the Support of Music Notation Software, Universal Journal of Educational Research, 7 (2019) 1726-1733.

[38] X. Ren, An investigation into the use of Music Notation Software by both European and Chinese composers, University of Sheffield, Department of Information Studies, 2009.

[39] B. Pinontoan, D. Paseru, D. Moroki, NUMBERED MUSICAL NOTATION EDITOR, DOI.

[40] Avshalomoff, Singer Win Big Ovation at Unique Concert, The China Press, January 20, 19365.

[41] J. Winzenburg, A New Multivoiced World: Polyphony and the First Chinese-Western Fusion Concerto, Journal of Musicological Research, 37 (2018) 209-238.

[42] W.Y. Chow, Twenty Chinese Instruments and" Concerto East and West."(Original Composition), DOI (1987).

[43] S. Tian, H. Liu, H. Tan, Enlightenment of" Long March Cantata": Rehearsal and Performance in the University Chorus Ensemble, DOI: 10.31235/osf.io/xygre (2020).

[44] S. Melvin, J. Cai, Rhapsody in Red: How Western Classical Music Became Chinese, Algora Publishing2004.

[45] 中华人民共和国教育部，2019 年全国高等学校名单， http://www.moe.gov.cn/jyb xxgk/s5743/s5744/201906/t20190617 386200.html, DOI (2019,Jun 15).

[46] H. Liu, S. Tian, J. Wang, H. Tan, Correction of" misunderstanding" about chorus in China: music terminology and discussion, DOI: $10.31235 /$ osf.io/hdqgr (2020).

[47] H. Liu, S. Tian, H. Tan, Analysis of "I love you, China": singing with de novo gesture and 
articulation, DOI: 10.31235/osf.io/4u82c (2020).

[48] S. Tian, H. Tan, Conception and Origination of folk tune in Long March Cantata (长征组歌), DOI: 10.31235/osf.io/cv86e (2020).

[49] M. Ogawa, Japan: Music as a tool for moral education?, The origins and foundations of music education, DOI (2010) 205-220.

[50] W.-C. Ho, The Sociopolitical Transformations and Hong Kong Secondary Music Education: Politicization, Culturalization, and Marketization, Bulletin of the Council for Research in Music Education, DOI (1999) 41-56.

[51] E.K. Wells, Green Fields of Illinois (University of Illinois Folksong Club Records.) Notes by Archie Green, faculty adviser, and staff of student producers. CFC 201 (1963). 12 in. LP. Accompanying 35-page booklet, Journal of the International Folk Music Council, 17 (1965) 79-79.

[52] D.K. Blake, University Geographies and Folk Music Landscapes: Students and Local Folksingers at the University of Illinois at Urbana-Champaign, 1961-1964, Journal of Musicology, 33 (2016) 92-116.

[53] W.G. Roy, Reds, whites, and blues: Social movements, folk music, and race in the United States, Princeton University Press2013.

[54] R.A. Reuss, J.C. Reuss, American folk music and left-wing politics, 1927-1957, Scarecrow Press2000.

[55] C. Wang, Professional Piano Education in Chinese Piano Music Culture, International Education Studies, 3 (2010) 92-95.

[56] C.C. Leung, Building a New Music Curriculum: A Multi-Faceted Approach, Action, Criticism, and Theory for Music Education, 3 (2004) n2.

[57] R.C. Kraus, Pianos and politics in China: Middle-class ambitions and the struggle over western music, Oxford University Press on Demand1989.

[58] W.-C. Ho, China: Socio-political constructions of school music, The origins and foundations of music education: Cross-cultural historical studies of music in compulsory schooling, DOI (2010) 189-204.

[59] J. Cai, Beethoven in China: How the Great Composer Became an Icon in the People's Republic: Penguin Specials, Penguin UK2015.

[60] M. Von Schoenebeck, The new German folk-like song and its hidden political messages Popular Music, 17 (1998) 279-292.

[61] R.D. Cohen, Folk music: the basics, Taylor \& Francis2006.

[62] W. Wiora, Concerning the conception of authentic folk music, Journal of the International Folk Music Council, 1 (1949) 14-19.

[63] A.J. Randall, Music, power, and politics, Routledge2004.

[64] M. Pickering, Recent folk music scholarship in England: a critique, Folk Music Journal, 6 (1990) 37-64.

[65] 何艳珊, 民乐的艺术创新与文化坚守, 光明日报, p12 (2017, Aug(24)).

[66] 张维良，创新传统民乐的当代表达（名师谈艺），人民日报, p20 ( 2019,Dec 20:).

[67] 李昆丽, 新民乐的融合之路与当前的审美缺失, 民族艺术研究, 5 (2005) 47-51.

[68] 何晓兵，新民乐：传统音乐的“×x 版”?, 中国音乐, 1 (2003) 13-14.

[69] H.-L. Yang, M. Saffle, The 12 girls band: Traditions, gender, globalization, and (inter) national identity, Asian music, 41 (2010) 88-112.

[70] J. Jin, 12 GIRLS BAND AND KODO: COMPARING OF INVENTED TRADITIONAL MUSIC IN CHINA AND JAPAN, DOI (2010). 
[71] I. Kodomari, T. Maruoka, R. Yamauchi, E. Wada, K. Wada, Ghrelin alters postnatal endocrine secretion and behavior in mouse offspring, Neurochemistry international, 54 (2009) 222-228.

[72] baidu 百科, 雅乐团, https://baike.baidu.com/item/雅乐团, DOI.

[73] A.m.t. association, Professional Requirements for Music Therapists: Educational Requirements for Music Therapists, https://www.musictherapy.org/about/requirements/, DOI.

[74] D. Degmečić, I. Požgain, P. Filaković, Music as Therapy/Glazba kao terapija, International Review of the Aesthetics and Sociology of Music, DOI (2005) 287-300.

[75] M. Cousineau, J.H. McDermott, I. Peretz, The basis of musical consonance as revealed by congenital amusia, Proceedings of the National Academy of Sciences of the United States of America, 109 (2012) 19858-19863.

[76] S. Malloch, C. Trevarthen, The Human Nature of Music, Frontiers in psychology, 9 (2018) 1680-1680.

[77] I. Winkler, G.P. Háden, O. Ladinig, I. Sziller, H. Honing, Newborn infants detect the beat in music, Proceedings of the National Academy of Sciences of the United States of America, 106 (2009) 2468-2471.

[78] L. Lordier, D.-E. Meskaldji, F. Grouiller, M.P. Pittet, A. Vollenweider, L. Vasung, C. Borradori-Tolsa, F. Lazeyras, D. Grandjean, D. Van De Ville, P.S. Hüppi, Music in premature infants enhances high-level cognitive brain networks, Proceedings of the National Academy of Sciences of the United States of America, 116 (2019) 12103-12108.

[79] K.E. Bruscia, Defining music therapy, Barcelona Publishers1998.

[80] E.I. Center, C.R. Center, P.F. Center, Music therapy, DOI (2014).

[81] L. Bunt, B. Stige, Music therapy: An art beyond words, Routledge2014.

[82] W.B. Davis, K.E. Gfeller, M.H. Thaut, An introduction to music therapy: Theory and practice, ERIC2008.

[83] M. Pavlicevic, G. Ansdell, Community music therapy, Jessica Kingsley Publishers2004.

[84] B. Stige, Culture-centered music therapy, The Oxford handbook of music therapy2002.

[85] B. Stige, L.E. Aarø, Invitation to community music therapy, Routledge 2011.

[86] M. Pavlicevic, Music therapy in context: Music, meaning and relationship, Jessica Kingsley Publishers1997.

[87] S. Guetin, F. Portet, M. Picot, C. Pommié, M. Messaoudi, L. Djabelkir, A. Olsen, M. Cano, E. Lecourt, J. Touchon, Effect of music therapy on anxiety and depression in patients with Alzheimer's type dementia: randomised, controlled study, Dementia and geriatric cognitive disorders, 28 (2009) $36-46$.

[88] T.R. Lord, J.E. Garner, Effects of music on Alzheimer patients, Perceptual and motor skills, 76 (1993) 451-455.

[89] M. Brotons, S.M. Koger, The impact of music therapy on language functioning in dementia, Journal of music therapy, 37 (2000) 183-195.

[90] C. Pacchetti, F. Mancini, R. Aglieri, C. Fundarò, E. Martignoni, G. Nappi, Active music therapy in Parkinson's disease: an integrative method for motor and emotional rehabilitation, Psychosomatic medicine, 62 (2000) 386-393.

[91] M.L. Im, J.I. Lee, Effects of art and music therapy on depression and cognitive function of the elderly, Technology and Health Care, 22 (2014) 453-458.

[92] H. Svansdottir, J. Snaedal, Music therapy in moderate and severe dementia of Alzheimer's type: a case-control study, International psychogeriatrics, 18 (2006) 613-621.

[93] A. Maratos, C. Gold, X. Wang, M. Crawford, Music therapy for depression, Cochrane database of 
systematic reviews, DOI (2008).

[94] J. Erkkilä, M. Punkanen, J. Fachner, E. Ala-Ruona, I. Pöntiö, M. Tervaniemi, M. Vanhala, C. Gold, Individual music therapy for depression: randomised controlled trial, The British journal of psychiatry, 199 (2011) 132-139.

[95] S. Castillo-Pérez, V. Gómez-Pérez, M.C. Velasco, E. Pérez-Campos, M.-A. Mayoral, Effects of music therapy on depression compared with psychotherapy, The Arts in Psychotherapy, 37 (2010) 387-390.

[96] K.-n. Zhou, X.-m. Li, Y. Hong, S.-n. Dang, D.-1. Wang, Effects of music therapy on depression and duration of hospital stay of breast cancer patients after radical mastectomy, Chinese medical journal, 124 (2011) 2321-2327.

[97] L. Chlan, Effectiveness of a music therapy intervention on relaxation and anxiety for patients receiving ventilatory assistance, Heart \& Lung, 27 (1998) 169-176.

[98] H. Wong, V. Lopez-Nahas, A. Molassiotis, Effects of music therapy on anxiety in ventilator-dependent patients, Heart \& Lung, 30 (2001) 376-387.

[99] J.M. White, Music therapy: an intervention to reduce anxiety in the myocardial infarction patient, Clinical nurse specialist CNS, 6 (1992) 58-63.

[100] F.A. Baker, L.M. Gleadhill, G.A. Dingle, Music therapy and emotional exploration: Exposing substance abuse clients to the experiences of non-drug-induced emotions, The Arts in Psychotherapy, 34 (2007) 321-330.

[101] T.L. Lesiuk, A Rationale for Music-Based Cognitive Rehabilitation Toward Prevention of Relapse in Drug Addiction, Music Therapy Perspectives, 28 (2010) 124-130.

[102] C. Gold, T.O. Heldal, T. Dahle, T. Wigram, Music therapy for schizophrenia or schizophrenia-like illnesses, Cochrane Database of Systematic Reviews, DOI (2005).

[103] K. Mössler, X. Chen, T.O. Heldal, C. Gold, Music therapy for people with schizophrenia and schizophrenia-like disorders, Cochrane Database of Systematic Reviews, DOI (2011).

[104] N. Talwar, M.J. Crawford, A. Maratos, U. Nur, O. McDermott, S. Procter, Music therapy for in-patients with schizophrenia: Exploratory randomised controlled trial, British Journal of Psychiatry, 189 (2018) 405-409.

[105] W. Tang, X. Yao, Z. Zheng, Rehabilitative Effect of Music Therapy for Residual Schizophrenia: A One-Month Randomised Controlled Trial in Shanghai, British Journal of Psychiatry, 165 (2018) 38-44.

[106] M. Geretsegger, C. Elefant, K.A. Mössler, C. Gold, Music therapy for people with autism spectrum disorder, Cochrane Database of Systematic Reviews, DOI (2014).

[107] A. Warwick, J. Alvin, Music therapy for the autistic child, Oxford University Press 1991.

[108] J. Kim, T. Wigram, C. Gold, Emotional, motivational and interpersonal responsiveness of children with autism in improvisational music therapy, Autism, 13 (2009) 389-409.

[109] A.E. Reschke-Hernández, History of music therapy treatment interventions for children with autism, Journal of Music Therapy, 48 (2011) 169-207.

[110] M. Boso, E. Emanuele, V. Minazzi, M. Abbamonte, P. Politi, Effect of long-term interactive music therapy on behavior profile and musical skills in young adults with severe autism, The journal of alternative and complementary medicine, 13 (2007) 709-712.

[111] D.S. Berger, Music therapy, sensory integration and the autistic child, Jessica Kingsley Publishers2002.

[112] E. Altenmüller, G. Schlaug, Neurologic music therapy: the beneficial effects of music making on neurorehabilitation, Acoustical Science and Technology, 34 (2013) 5-12. 
[113] J. Bradt, W.L. Magee, C. Dileo, B.L. Wheeler, E. McGilloway, Music therapy for acquired brain injury, Cochrane Database of Systematic Reviews, DOI (2010).

[114] S. Nayak, B.L. Wheeler, S.C. Shiflett, S. Agostinelli, Effect of music therapy on mood and social interaction among individuals with acute traumatic brain injury and stroke, Rehabilitation Psychology, 45 (2000) 274.

[115] M. Thaut, J. Gardiner, D. Holmberg, J. Horwitz, L. Kent, G. Andrews, B. Donelan, G. Mcintosh, Neurologic music therapy improves executive function and emotional adjustment in traumatic brain injury rehabilitation, Annals of the New York Academy of Sciences, 1169 (2009) 406-416.

[116] E. Economidou, A. Klimi, V.G. Vivilaki, K. Lykeridou, Does music reduce postoperative pain? A review, Health Science Journal, 6 (2012) 365-377.

[117] A.K. Leins, R. Spintge, Music therapy in medical and neurological rehabilitation settings, Oxford Handbook of Music Psychology2009.

[118] C. Thaut, K.M. Stephan, Neurologic music therapy in sensorimotor rehabilitation, The Oxford Handbook of Music and the Brain2005.

[119] A. Vink, Music and emotion: Living apart together: A relationship between music psychology and music therapy, Nordic Journal of Music Therapy, 10 (2001) 144-158.

[120] S.E. Sendelbach, M.A. Halm, K.A. Doran, E.H. Miller, P. Gaillard, Effects of music therapy on physiological and psychological outcomes for patients undergoing cardiac surgery, Journal of cardiovascular nursing, 21 (2006) 194-200.

[121] T.N. Nguyen, S. Nilsson, A.-L. Hellström, A. Bengtson, Music Therapy to Reduce Pain and Anxiety in Children With Cancer Undergoing Lumbar Puncture: A Randomized Clinical Trial, Journal of Pediatric Oncology Nursing, 27 (2010) 146-155.

[122] J. Bradt, N. Potvin, A. Kesslick, M. Shim, D. Radl, E. Schriver, E.J. Gracely, L.T. Komarnicky-Kocher, The impact of music therapy versus music medicine on psychological outcomes and pain in cancer patients: a mixed methods study, Supportive Care in Cancer, 23 (2015) 1261-1271.

[123] L. Magill, The use of music therapy to address the suffering in advanced cancer pain, Journal of palliative care, 17 (2001) 167.

[124] C.C. O'Callaghan, Pain, music creativity and music therapy in palliative care, American Journal of Hospice and Palliative Medicine®, 13 (1996) 43-49.

[125] K.J. Gutgsell, M. Schluchter, S. Margevicius, P.A. DeGolia, B. McLaughlin, M. Harris, J. Mecklenburg, C. Wiencek, Music therapy reduces pain in palliative care patients: a randomized controlled trial, Journal of pain and symptom management, 45 (2013) 822-831.

[126] R.E. Hilliard, Music therapy in hospice and palliative care: a review of the empirical data, Evidence-Based Complementary and Alternative Medicine, 2 (2005) 173-178.

[127] L.M. Gallagher, R. Lagman, D. Walsh, M.P. Davis, S.B. LeGrand, The clinical effects of music therapy in palliative medicine, Supportive care in cancer, 14 (2006) 859-866.

[128] B. Trauger-Querry, K.R. Haghighi, Balancing the focus: Art and music therapy for pain control and symptom management in hospice care, The Hospice Journal, 14 (1999) 25-38.

[129] R.E. Krout, Music therapy with imminently dying hospice patients and their families: Facilitating release near the time of death, American Journal of Hospice and Palliative Medicine ${ }^{\circ}, 20$ (2003) 129-134.

[130] M. Critchley, R.A. Henson, Music and the Brain: Studies in the Neurology of Music, Butterworth-Heinemann2014.

[131] Music Therapy Around the World and on the Web, https://www.musictherapy.org/about/listserv/, DOI. 
[132] 音乐治疗行业委员会, 音乐治疗师资格考试, http://www.chinamusictherapy.org/8.html, DOI.

[133] H.A. Lingerman, The healing energies of music, Quest Books1995.

[134] M. Dixon, Music and human rights, Music, music therapy and trauma: International perspectives, DOI (2002) 119-132.

[135] J.P. Sutton, Music, music therapy and trauma: International perspectives, Jessica Kingsley Publishers2002.

[136] E.T. Gaston, Dynamic music factors in mood change, Music Educators Journal, 37 (1951) 42-44.

[137] S.C. Jones, T.G. Schumacher, Muzak: On functional music and power, Critical Studies in Media Communication, 9 (1992) 156-169.

[138] M. Digiammarino, Functional music leisure skills for individuals with mental retardation, Music therapy perspectives, 12 (1994) 15-19.

[139] P. Pichot, The effect of rhythm and functional music on mental defectives, Mental Health, 9 (1949) 6.

[140] W. Guo, J. Ren, B. Wang, Q. Zhu, Effects of relaxing music on mental fatigue induced by a continuous performance task: behavioral and ERPs evidence, PloS one, 10 (2015).

[141] R.L. Cardinell, Music in industry, DOI (1948).

[142] R. Cardinell, The statistical method in determining the effects of music in industry, The Journal of the Acoustical Society of America, 15 (1943) 133-135.

[143] J.F. Humes, The effects of occupational music on scrappage in the manufacture of radio tubes, Journal of Applied Psychology, 25 (1941) 573-587.

[144] S. Juan, The Role and Function of Functional Music in Sports Activities [J], Journal Liaoning Normal University, 4 (2006).

[145] S. Jie, A Research on the Body-building Function of Music Sports [J], Sichuan Sports Science, 3 (2002).

[146] G. Vaillancourt, Multicultural music therapy as an instrument for leadership: Listening-vision-process, Voices: A World Forum for Music Therapy, 2007.

[147] R.E. Krout, The attraction of the guitar as an instrument of motivation, preference, and choice for use with clients in music therapy: A review of the literature, The Arts in Psychotherapy, 34 (2007) $36-52$.

[148] A.G. Dagger, Principal Instruments in Music Therapy Practice: An Art-Based Research Community Engagement Project, DOI (2019).

[149] M. Belgrave, The effect of a music therapy intergenerational program on children and older adults' intergenerational interactions, cross-age attitudes, and older adults' psychosocial well-being, Journal of music therapy, 48 (2011) 486-508.

[150] H.M.O. Ridder, B. Stige, L.G. Qvale, C. Gold, Individual music therapy for agitation in dementia: an exploratory randomized controlled trial, Aging \& mental health, 17 (2013) 667-678.

[151] S. Garrido, J. Davidson, H. Odell-Miller, Music and mood regulation: A historical enquiry into individual differences and musical prescriptions through the ages, Australian Journal of Music Therapy, 24 (2013) 89.

[152] E.I. Center, C.R. Center, P.F. Center, Music therapy, https://www1.cgmh.org.tw/intr/intr2/c3390/en/music-therapy.htm, DOI (2014).

[153] M.J. Silverman, M.J. Hairston, A descriptive study of private practice in music therapy, Journal of Music Therapy, 42 (2005) 262-272.

[154] J. Loewy, Medical music therapy for children, Music therapy handbook, Guilford Press, New York2015, pp. 425-440. 
[155] K.M. Chase, Music Therapy Assessment for Children with Developmental Disabilities: A Survey Study, Journal of Music Therapy, 41 (2004) 28-54.

[156] R.J. Starr, Music therapy in hospice care, American Journal of Hospice and Palliative Medicine ${ }^{\circledR}$, 16 (1999) 739-742.

[157] M. Suzuki, M. Kanamori, M. Watanabe, S. Nagasawa, E. Kojima, H. Ooshiro, D. Nakahara, Behavioral and endocrinological evaluation of music therapy for elderly patients with dementia, Nursing \& Health Sciences, 6 (2004) 11-18.

[158] B.A. Bailey, J.W. Davidson, Amateur group singing as a therapeutic instrument, Nordic journal of music therapy, 12 (2003) 18-32.

[159] 李志民, 为“第二学士学位”重新归来叫好, 中国科学报、科学网、科学新闻杂志, http://news.sciencenet.cn/htmlnews/2020/5/439666.shtm.

[160] 李天晓，探析当代新民乐的现状与发展态势，戏剧之家, 03 (2018) 65. 
表 1. 锦州医科大学民乐社团成员信息

\begin{tabular}{|c|c|c|c|c|c|c|}
\hline 序号 & 成员姓名 & 演奏乐器 & 考级水平 & 演奏水平 & 奖学金 & 所在学院 \\
\hline 1 & 姜禹辰 & 二胡 & 十级 & 优等 & 有 & 人文管理 \\
\hline 2 & 赵鹏 & 二胡 & 未考级 & 优等 & 无 & 人文管理 \\
\hline 3 & 李俣豪 & 二胡 & 十级 & 优等 & 有 & 一临床 \\
\hline 4 & 王植辰 & 二胡 & 未考级 & 中等 & 无 & 一临床 \\
\hline 5 & 李妍琦 & 二胡 & 十级 & 优等 & 有 & 一临床 \\
\hline 6 & 陈明澈 & 二胡 & 九级 & 优等 & 有 & 一临床 \\
\hline 7 & 金子 & 二胡 & 十级 & 中等 & 无 & 一临床 \\
\hline 8 & 何珈羽涵 & 二胡 & 六级 & 优等 & 无 & 一临床 \\
\hline 9 & 罗宁 & 二胡 & 七级 & 优等 & 无 & 三临床 \\
\hline 10 & 程诺 & 二胡 & 十级 & 优等 & 无 & 高职 \\
\hline 11 & 孙艈倩 & 琵琶 & 十级 & 优等 & 无 & 一临床 \\
\hline 12 & 吴粀 & 琵琶 & 五级 & 优等 & 无 & 一临床 \\
\hline 13 & 曲玲慧 & 琵琶 & 十级 & 优等 & 无 & 一临床 \\
\hline 14 & 刘姿麟 & 琵琶 & 十级 & 优等 & 无 & 一临床 \\
\hline \multirow[t]{2}{*}{15} & 郭紫丹 & 琵琶 & 未考级 & 中等 & 无 & 一临床 \\
\hline & & 钢琴 & 十级 & 优等 & 无 & \\
\hline 16 & 梁㴋方 & 古笔 & 十级 & 优等 & 有 & 一临床 \\
\hline 17 & 侯力铭 & 古笔 & 十级 & 优等 & 无 & 一临床 \\
\hline 18 & 李晨硕 & 古筝 & 十级 & 中等 & 无 & 一临床 \\
\hline 19 & 梁笑慈 & 古筝 & 十级 & 优等 & 无 & 一临床 \\
\hline 20 & 王奕金鍂 & 古筝 & 未考级 & 中等 & 无 & 三临床 \\
\hline 21 & 杜函佩 & 古筝 & 五级 & 中等 & 无 & 三临床 \\
\hline 22 & 单玉雪 & 古笔 & 十级 & 中等 & 无 & 三临床 \\
\hline 23 & 蔡瑶 & 古筝 & 十级 & 优等 & 无 & 三临床 \\
\hline \multirow[t]{2}{*}{24} & 涂琼丹 & 古等 & 八级 & 优等 & 无 & 三临床 \\
\hline & & 中阮 & 三级 & 优等 & 无 & \\
\hline 25 & 再江浩 & 笛子 & 未考级 & 中等 & 无 & 人文管理 \\
\hline 26 & 孙悦怡 & 笛子 & 十级 & 中等 & 无 & 三临床 \\
\hline 27 & 程芷琳 & 笛子 & 十级 & 优等 & 无 & 口腔 \\
\hline 28 & 王浩成 & 笛子 & 未考级 & 中等 & 无 & 三临床 \\
\hline 29 & 吴欣怡 & 葫芦丝 & 未考级 & 优等 & 无 & 三临床 \\
\hline 30 & 陈宏怡灿 & 葫芦丝 & 八级 & 中等 & 有 & 三临床 \\
\hline 31 & 李秋爽 & 古琴 & 未考级 & 中等 & 无 & 一临床 \\
\hline 32 & 刘依萍 & 古琴 & 未考级 & 中等 & 无 & 一临床 \\
\hline 33 & 迪力木拉提 & 吉他 & 未考级 & 优等 & 无 & 三临床 \\
\hline 34 & 秦宁忆 & 吉他 & 未考级 & 优等 & 无 & 三临床 \\
\hline 35 & 阿依布力 & 吉他 & 未考级 & 中等 & 无 & 三临床 \\
\hline 36 & 曹月 & 吉他 & 未考级 & 中等 & 无 & 护理 \\
\hline 37 & 刘建瑛 & 八孔箫 & 未考级 & 中等 & 无 & 康复 \\
\hline 38 & 毕侨益 & 巴乌 & 六级 & 优等 & 无 & 康复 \\
\hline 39 & 范栩辰 & 笙 & 十级 & 优等 & 无 & 一临床 \\
\hline 40 & 阿友西 & 马头琴 & 中专毕业 & 优等 & 无 & 人文管理 \\
\hline 41 & 程钰哲 & 电音 & 未考级 & 优等 & 无 & 三临床 \\
\hline
\end{tabular}


表 2. 锦州医科大学民乐社团具体情况

\begin{tabular}{cccccc}
\hline 成立时间 & 排练时间 & 指导教师 & 指挥 & 演出场次/年 & 所得经费/年 \\
\hline 2013 年 & 每周二、周四 & 田思宇 & 姜禹辰 & $6-9$ 次 & $1000-3000$ 不等 \\
& (节假日有休息) & & & & (视具体情况而定) \\
\hline
\end{tabular}

表 3. 锦州医科大学民乐社团训练曲目

\begin{tabular}{|c|c|c|c|c|c|}
\hline \multicolumn{6}{|c|}{ 锦州医科大学民乐社团训练曲目 } \\
\hline 训练曲目 & 演奏形式 & 乐曲风格 & 是否改编 & 小节 & 演奏时长 \\
\hline 赛马 & 民乐合奏 & 传统音乐 & 是 & 121 & 2 分 08 秒 \\
\hline 十面埋伏 & 琵琶合奏 & 传统音乐 & 否 & 336 & 6 分 59 秒 \\
\hline 金蛇狂舞 & 民乐合奏 & 传统音乐 & 否 & 65 & 2 分 40 秒 \\
\hline 春江花月夜 & 民乐合奏 & 传统音乐 & 否 & 237 & 9 分 11 秒 \\
\hline 步步高 & 民乐合奏 & 传统音乐 & 否 & 133 & 3 分 12 秒 \\
\hline 梁祝 & 民乐合奏 & 传统音乐 & 是 & 82 & 3 分 03 秒 \\
\hline 渔舟唱晚 & 古筝合奏 & 传统音乐 & 是 & 69 & 4 分 48 秒 \\
\hline 彩云追月 & 民乐合奏 & 传统音乐 & 是 & 25 & 3 分 37 秒 \\
\hline 知否知否应是雪落下的声音 & 民乐合奏 & 影视插曲 & 是 & 28 & 5 分 16 秒 \\
\hline 沂蒙颂 & 民乐合奏 & 影视插曲 & 是 & 63 & 2 分 17 秒 \\
\hline 在水一方 & 古筝合奏 & 影视插曲 & 是 & 66 & 2 分 56 秒 \\
\hline 红梅赞 & 古筝合奏 & 影视插曲 & 是 & 26 & 2 分 \\
\hline 九儿 & 民乐合奏 & 影视插曲 & 是 & 34 & 2 分 32 秒 \\
\hline 绒花 & 民乐合奏 & 影视插曲 & 是 & 49 & 3 分 15 秒 \\
\hline 加勒比海盗 & 民乐合奏 & 影视插曲 & 是 & 86 & 1 分 30 秒 \\
\hline Let's play again & 民乐合奏 & 游戏音乐 & 是 & 29 & 2 分 23 秒 \\
\hline Victory & 民乐合奏 & 游戏音乐 & 是 & 100 & 5 分 20 秒 \\
\hline Phoenix & 民乐合奏 & 游戏音乐 & 是 & 67 & 2 分 25 秒 \\
\hline 斗地主背景 & 民乐合奏 & 游戏音乐 & 是 & 82 & 1 分 46 秒 \\
\hline 芒种 & 民乐合奏 & 流行古风 & 是 & 58 & 3 分 36 秒 \\
\hline 广寒宫 & 民乐合奏 & 流行古风 & 是 & 60 & 3 分 36 秒 \\
\hline 大碗宽面 & 民乐合奏 & 流行古风 & 是 & 84 & 3 分 41 秒 \\
\hline 火红的萨日朗 & 民乐合奏 & 流行古风 & 是 & 34 & 4 分 27 秒 \\
\hline 探清水河 & 民乐合奏 & 流行古风 & 是 & 12 & 3 分 38 秒 \\
\hline 出山 & 民乐合奏 & 流行古风 & 是 & 37 & 3 分 20 秒 \\
\hline Bad guy & 民乐合奏 & 流行英文 & 是 & 111 & 3 分 14 秒 \\
\hline 九九八十一 & 民乐合奏 & 二次元漫改 & 是 & 46 & 4 分 47 秒 \\
\hline 权御天下 & 民乐合奏 & 二次元漫改 & 是 & 192 & 4 分 10 秒 \\
\hline
\end{tabular}

\section{注: 乐谱均来源于中国曲谱网}




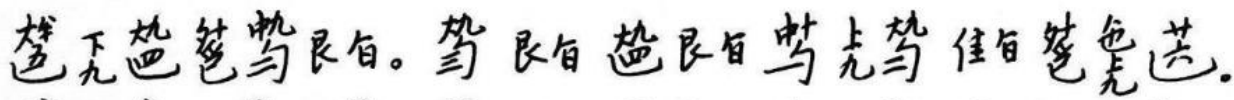 \\ 夜色茫茫, 罩四周天边新月如钧。 \\ 夜色朦朦, 夜未尽周遭寂寞宁静。}

图 1. 中国工尺谱注释

引自 Source: http://pu. guqu. net/guqin/20090805224646 3834.htm1

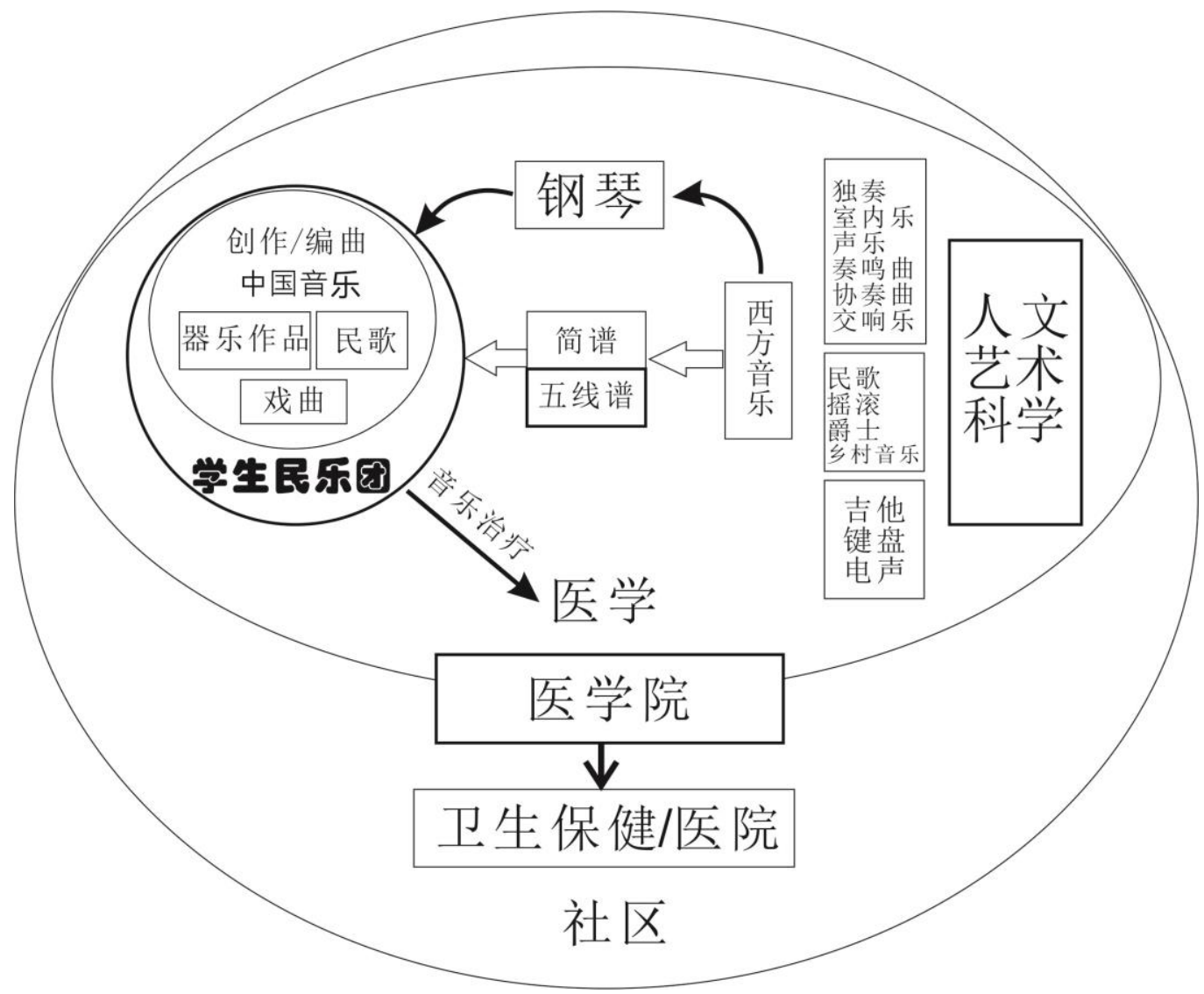

图 2. 医学院学生民乐团应该成为音乐治疗的桥梁: 医学专业学生民乐社团活动对学生的兴 趣爱好结合专业学习的互惠作用及其医学教育作用。音乐疗愈对某些病症有积极的作用。我 们的实际排练和演出体会到, 民族乐器在低音区的和声表现有些欠缺, 认为配器应用钢琴的 可以丰富有些作品表现力。 


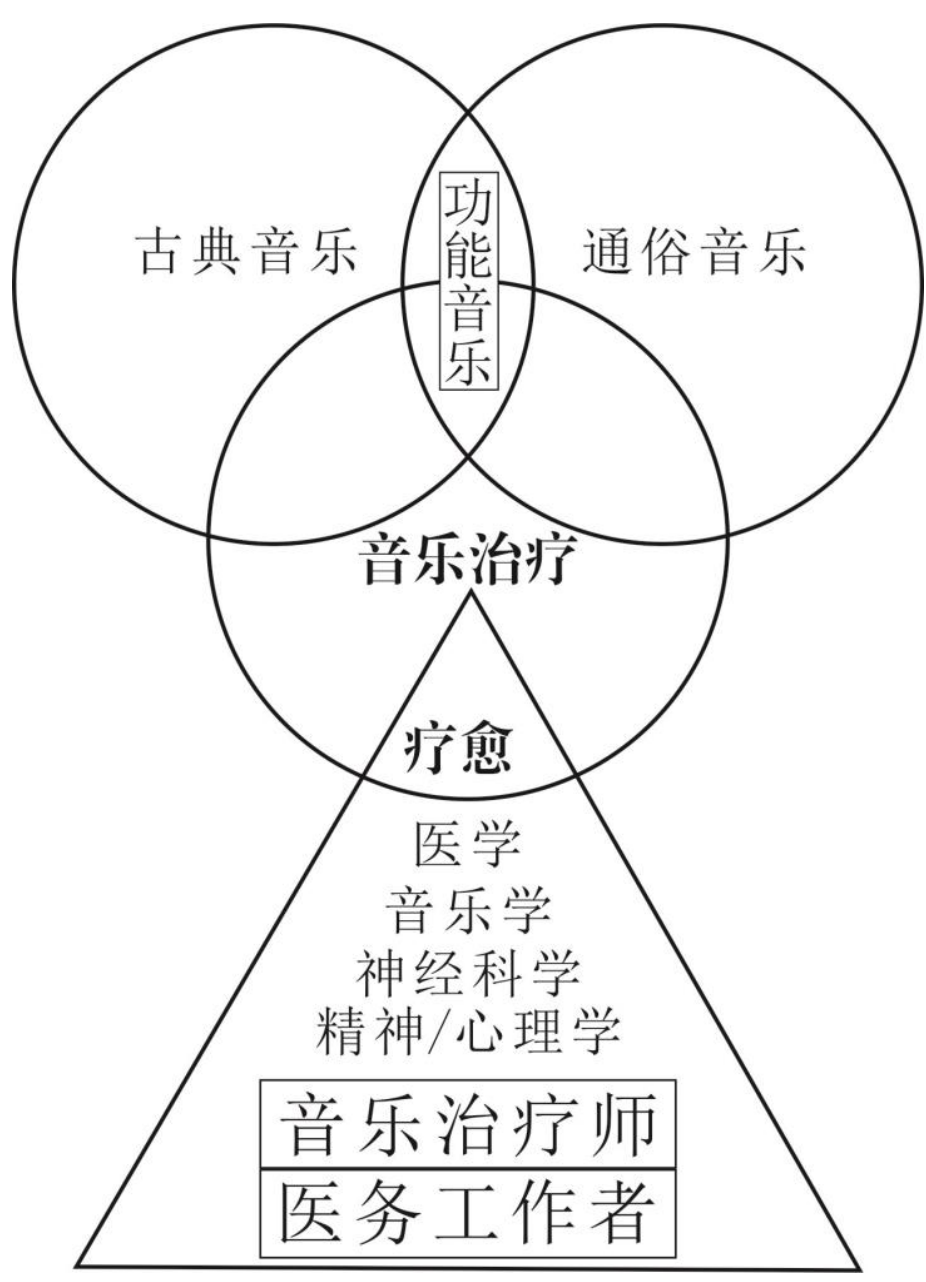

图 3. 音乐医学应用模式。在古典音乐和通俗音乐中, 派生出功能音乐, 部分概念和应用, 与音乐治疗相互融合。通过医学, 音乐学, 神经科学, 精神/心理学等学科结合, 形成一种 专业交叉学科领域。 


\begin{tabular}{|c|}
\hline 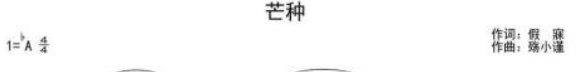 \\
\hline 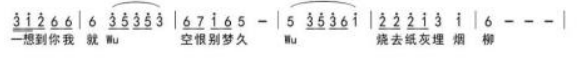 \\
\hline 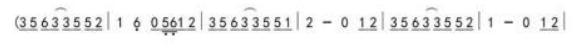 \\
\hline 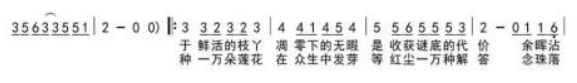 \\
\hline 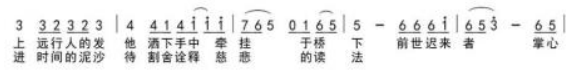 \\
\hline 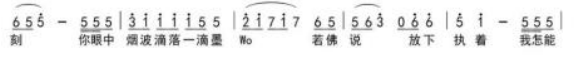 \\
\hline 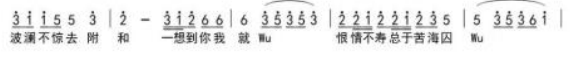 \\
\hline 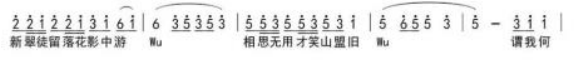 \\
\hline 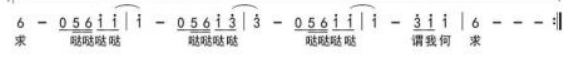 \\
\hline
\end{tabular}

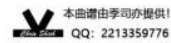

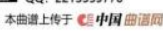

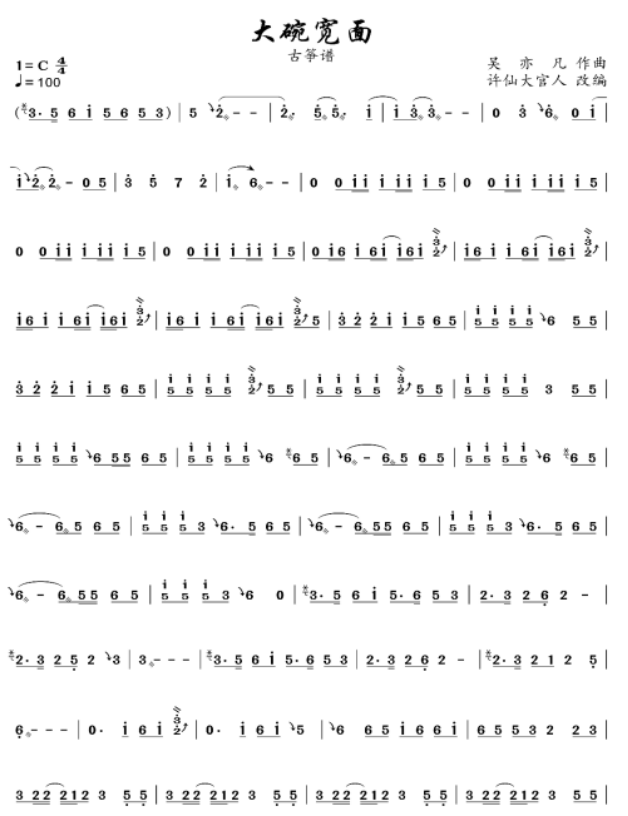

$$
1=E \frac{4}{4}
$$

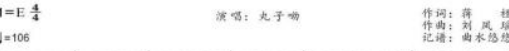

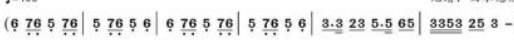

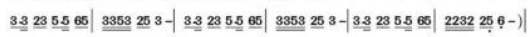

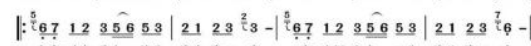

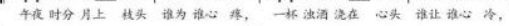

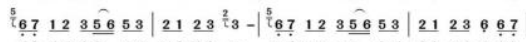

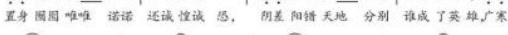

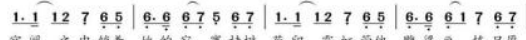

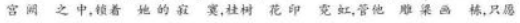
1. $12765|6.667567| 1.112765 \mid 67655^{\circ} 60$

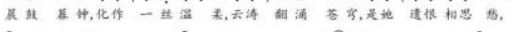

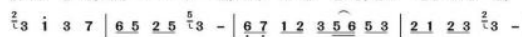

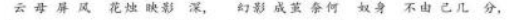

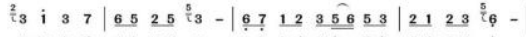

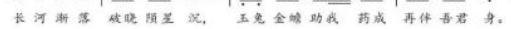

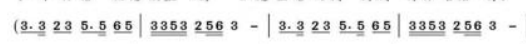

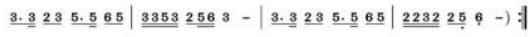

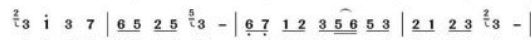

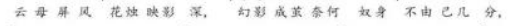

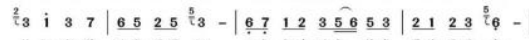
स त

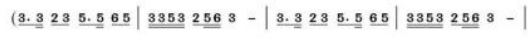

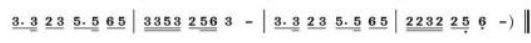

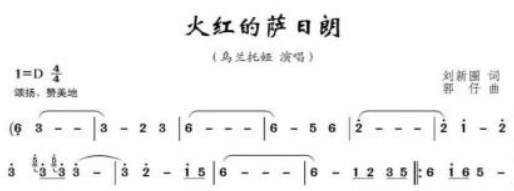

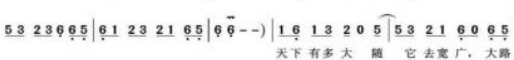
$\left.1162352\right|^{2} 3--17|6132.5| 53223665 \mid \hat{61223} 2161$

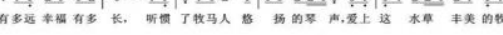
$\hat{166-0 \mid 1653205} \widehat{5} 33216065|1162352| 3--17$

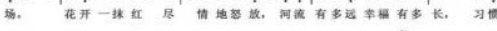

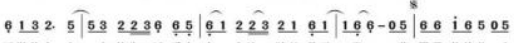

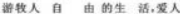

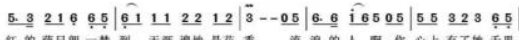

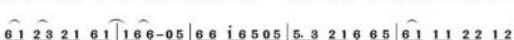

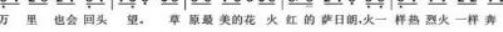

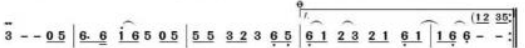

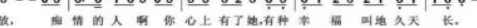


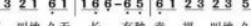
123518 in 5

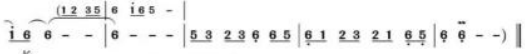

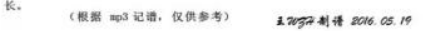




\section{卡凍巴《舛地主》演奏橧}

微信公众号【众乐音圈】选调：17音C洞

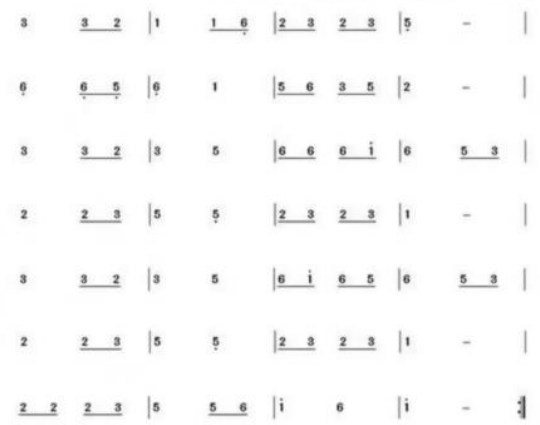

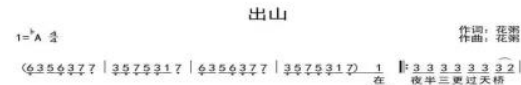

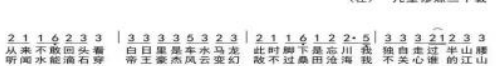

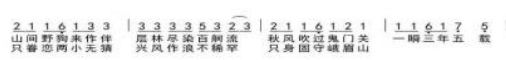

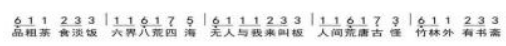

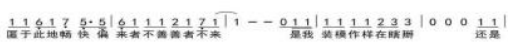

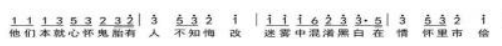

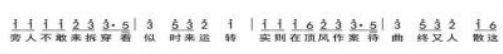

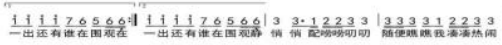

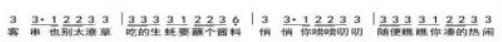

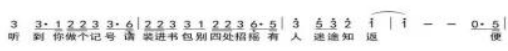

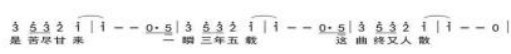

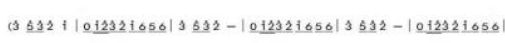

$3532+\mid 01232+056) \mid$

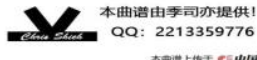

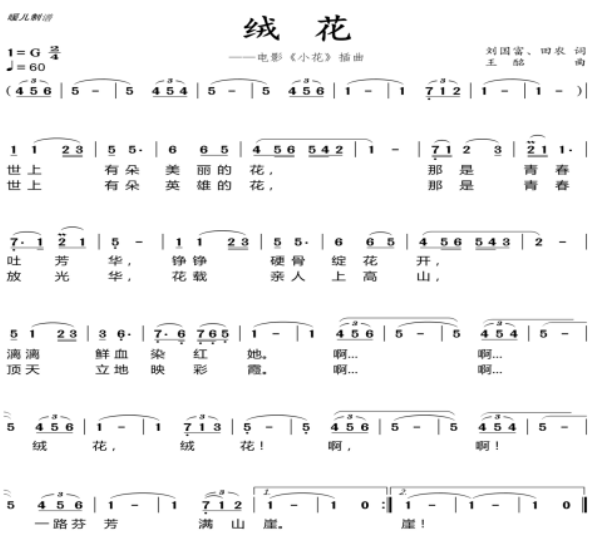

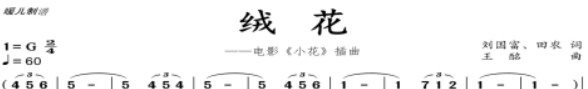$$
\overparen { 7 . 1 } \overparen { 2 1 } | 5 - | 1 \longdiv { 2 3 } | 5 5 . | 6 \widehat { 6 5 } | \longdiv { 4 5 6 5 4 3 | 2 } - |
$$

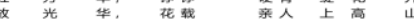

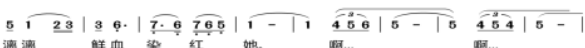

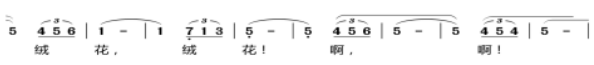

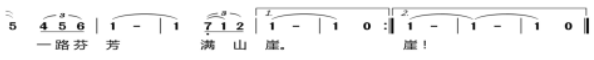

探 清 水 河

\section{$1=E \frac{2}{4}$

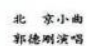

(555 6532| 1.2 $165|1651231| \underline{1}$.1 612 | 5556532

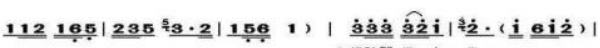

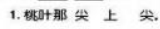

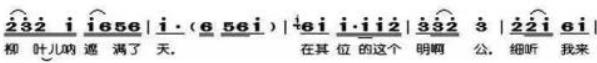

Hit

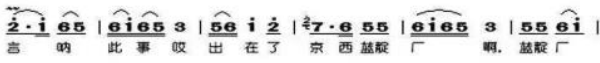
(15 13)

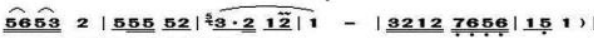

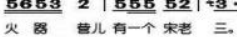

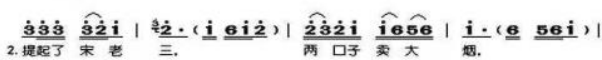

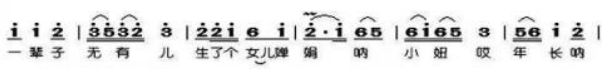

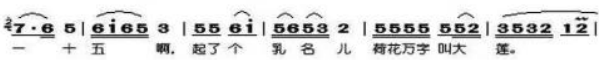
(15 13)

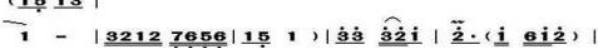

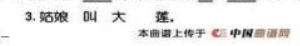

在水一方

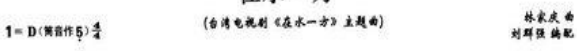

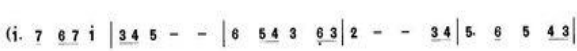

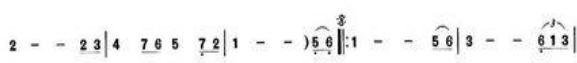

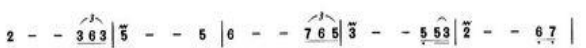

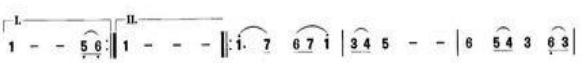

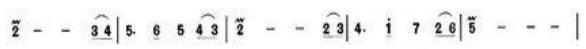

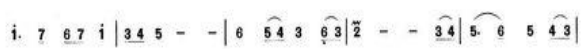

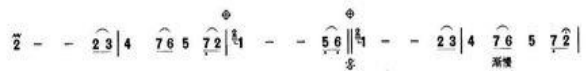

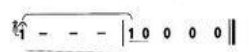

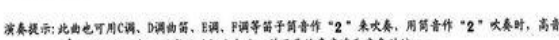

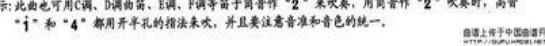

\section{红 梅 兟}

歌制《江姐》选曲

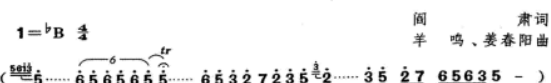

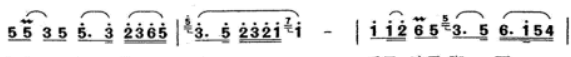
红岩上红梅开, 千里冰霜脚下

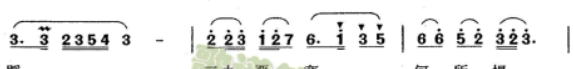

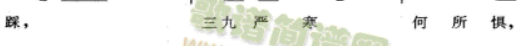

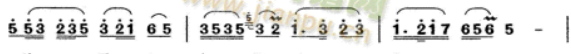
一片看向阳开, 阳开。

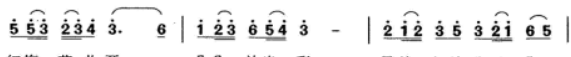
红梅花儿开, 朵朵放光影, 昂首怒放花石朵,

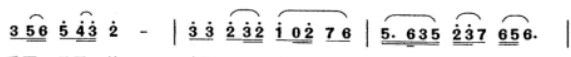
香䃌云天外, 㛟醒百花齐开放,

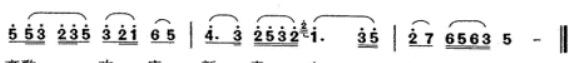




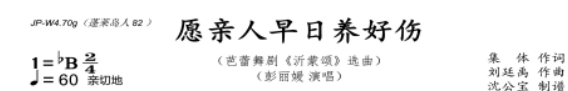

( $\dot{3} \cdot \underline{\underline{2} \dot{3}}|\mathbf{i} \quad 5| \underline{\dot{2} \cdot \dot{3}} \underline{\underline{i} 765}|\dot{2}-| \dot{3} \cdot \underline{\underline{2} \dot{3}}|\underline{\underline{i} \mathbf{i}} 6|$

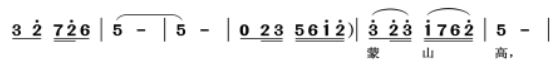

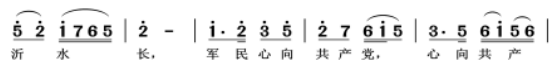

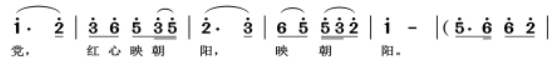

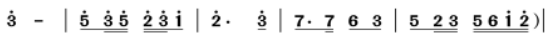

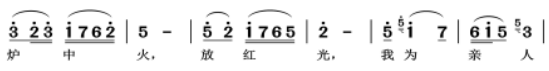

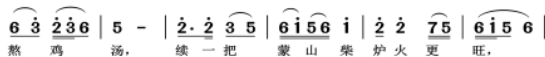

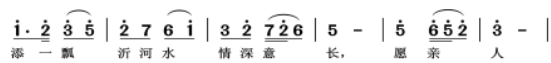

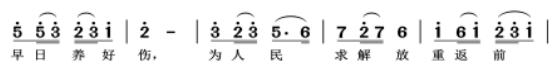

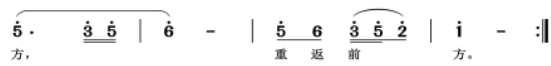

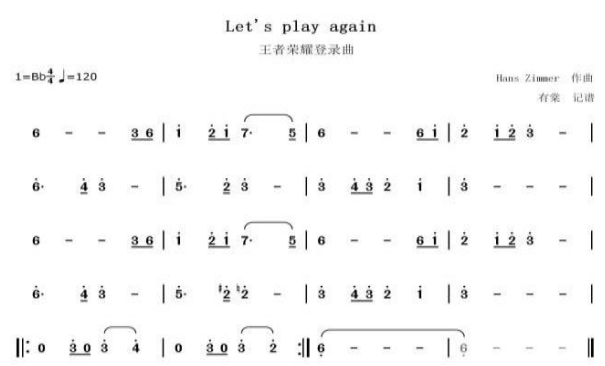




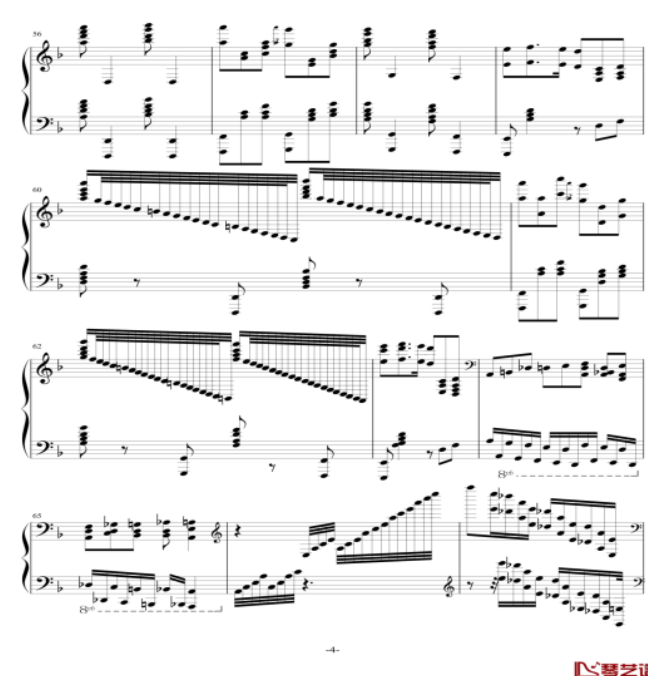

Everyone Piano

Phoenix

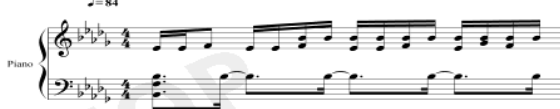

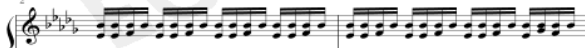

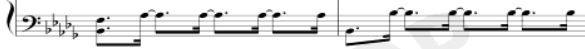

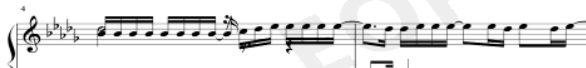

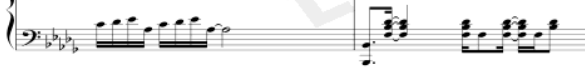

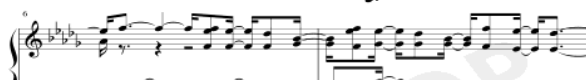

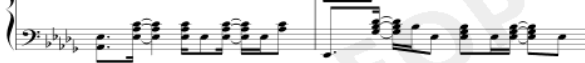

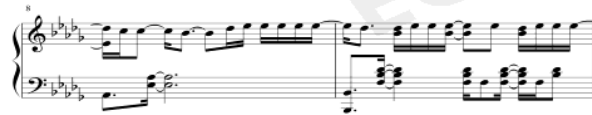

Everyone Piano

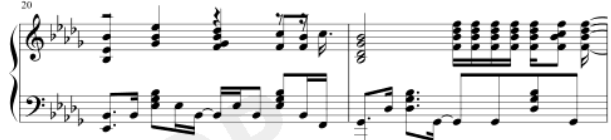

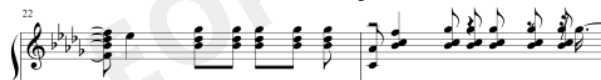

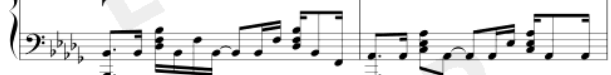

$\left(b_{3}\right) \div \vdots \vdots \vdots \ldots \ldots \ldots \ldots$

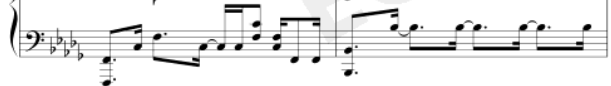

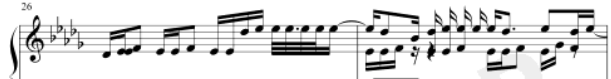

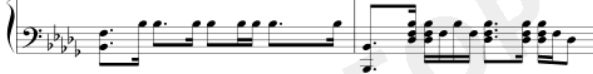

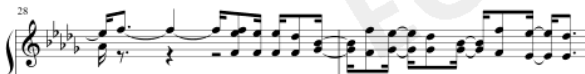

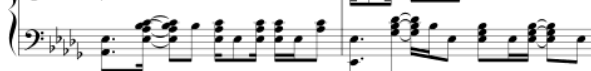

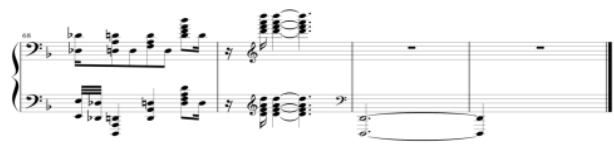

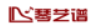

Everyone Piano
vww.

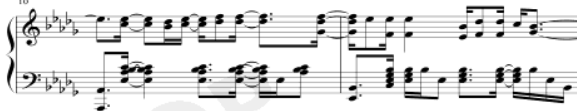

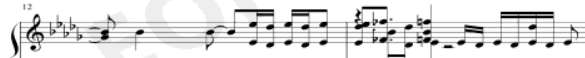
$\{\ldots \ldots 0 \quad \ldots \ldots$

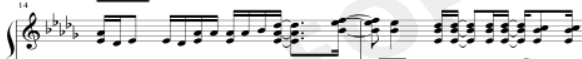
(9,b, $\because \because \because \cdots$

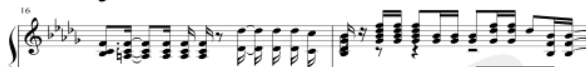

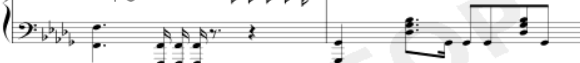

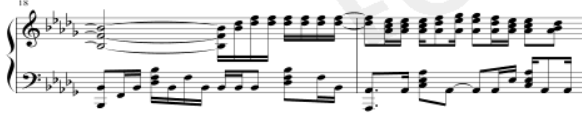

Everyone Piano

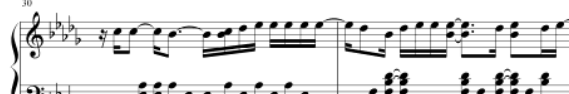

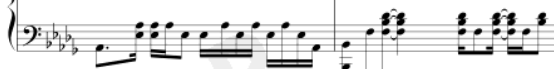

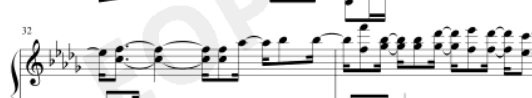

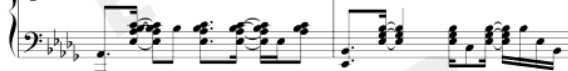

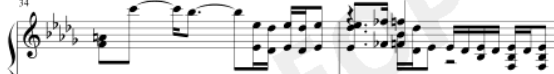

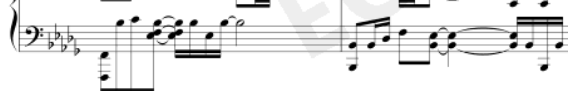

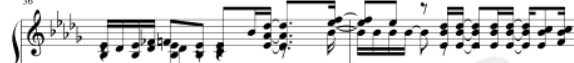
(q)b,

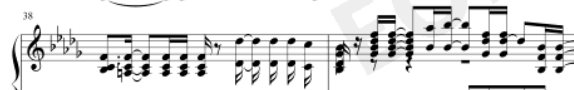

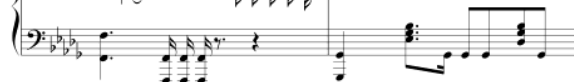


Everyone Pian

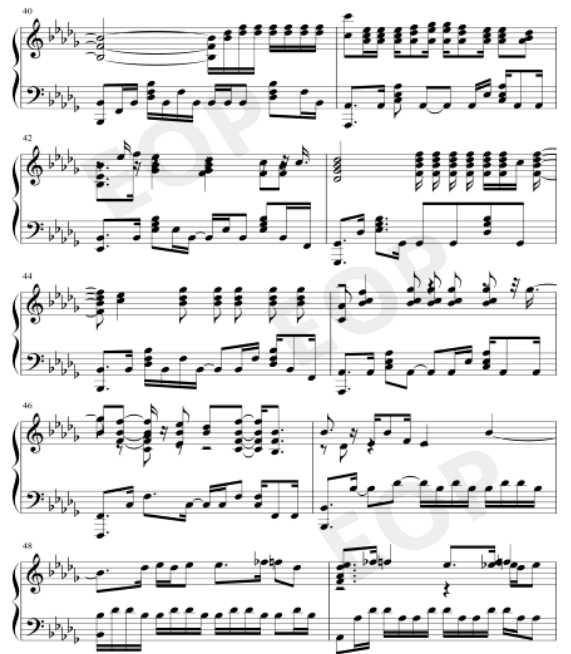

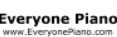
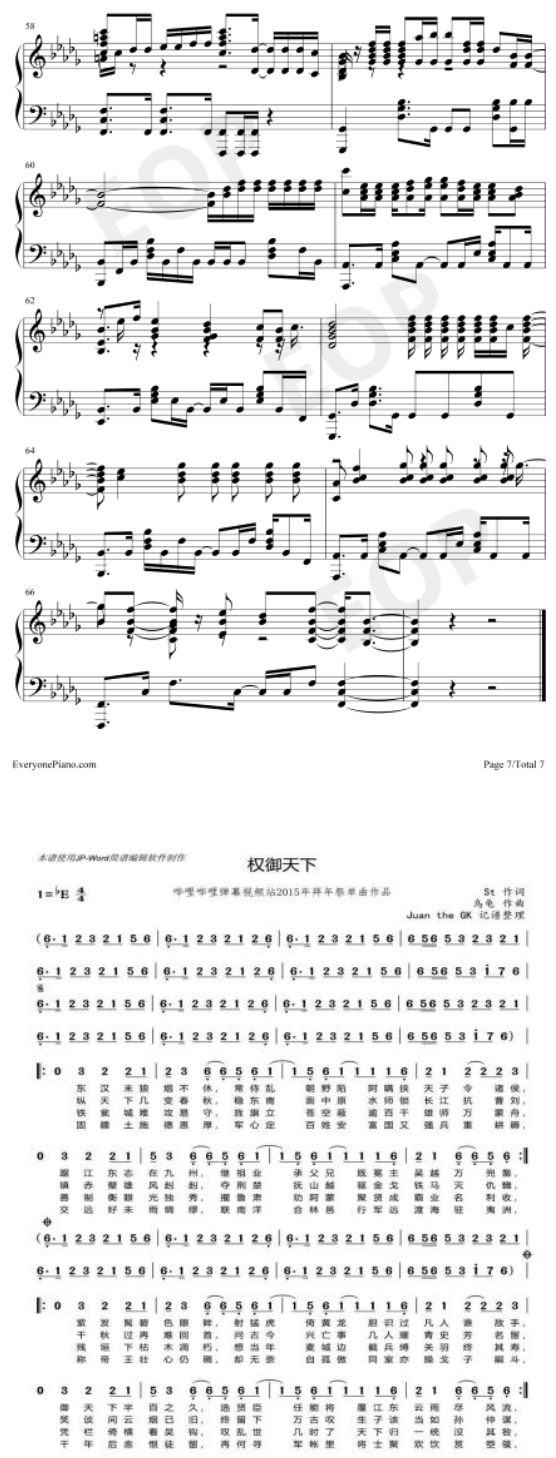

Everyone Piano

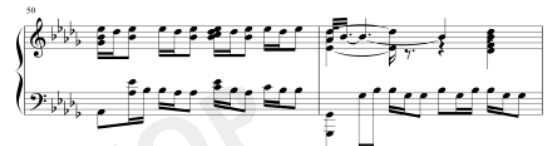

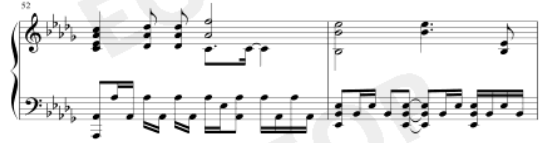

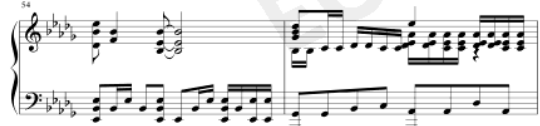

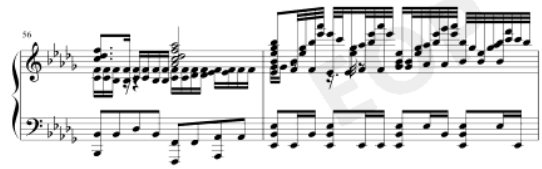

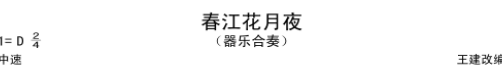

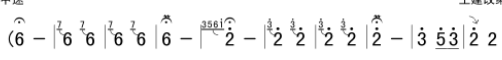

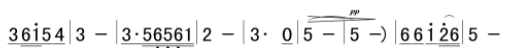

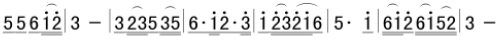

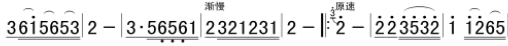

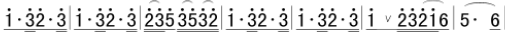

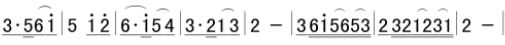

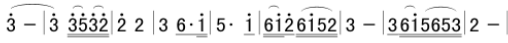

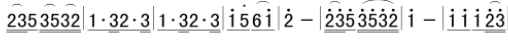

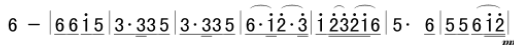
$3-|36 \hat{15653}| 2 \times 321231|2-||\dot{2} \dot{3} \dot{2} \dot{i} \dot{2} \dot{3} \dot{2-\mid \dot{2}}-|$

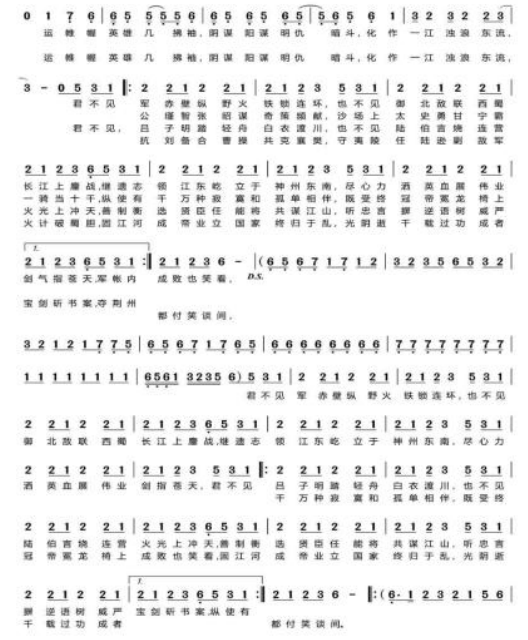



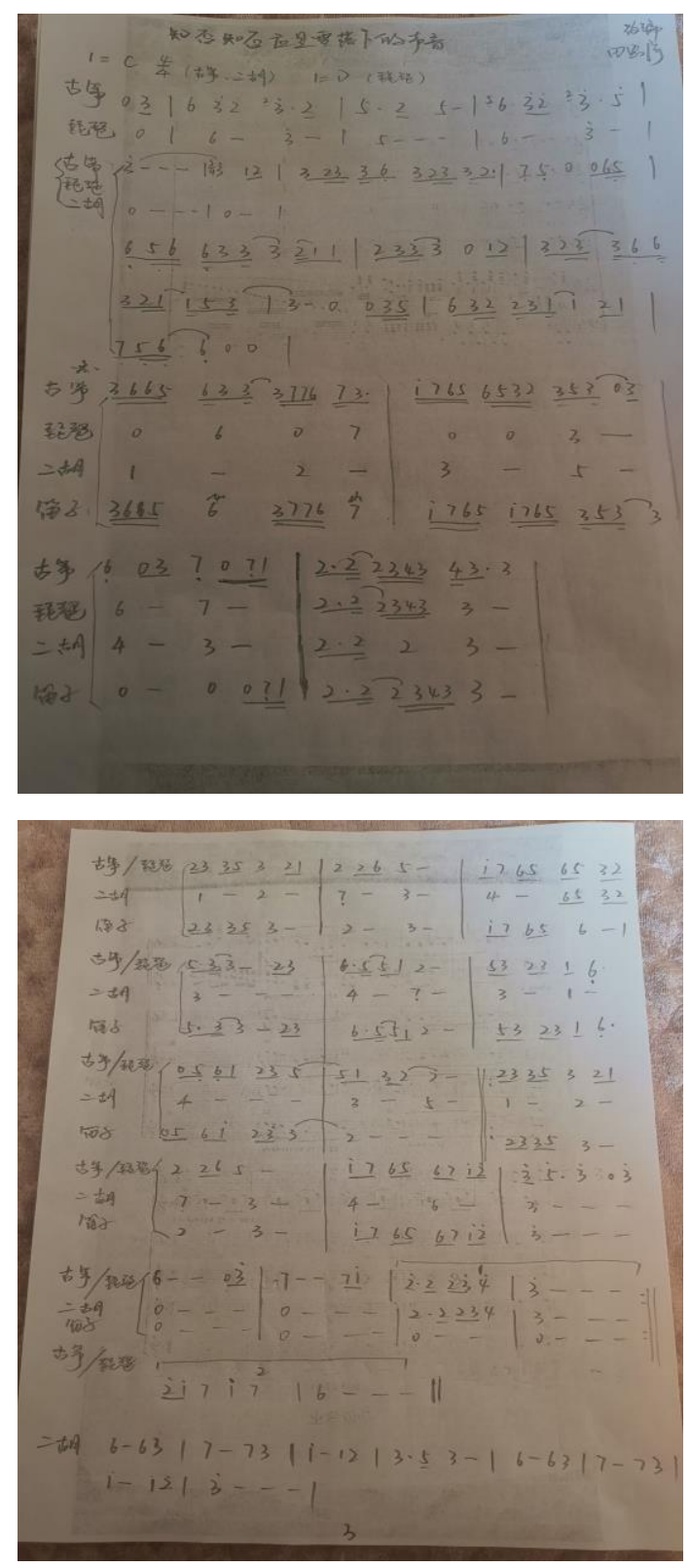

$5544|5522| 2545|6922| 4224|5556| i|i 6 i| i 655 \mid$

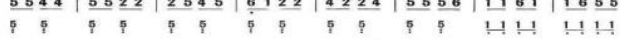
$5854|2225| 5243|2244| 6124 T 465$ |665|6i56|

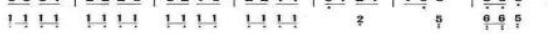

i i $56 \mid \begin{array}{ll}42 \\ 40\end{array}$ 4 5.656|545 | i- 4 -

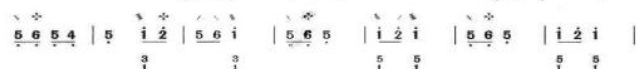

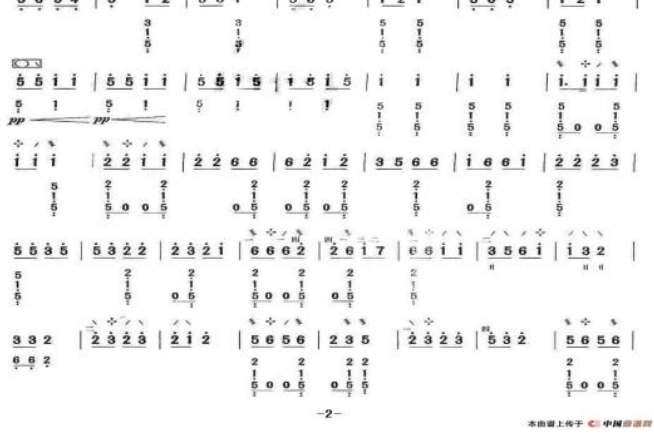

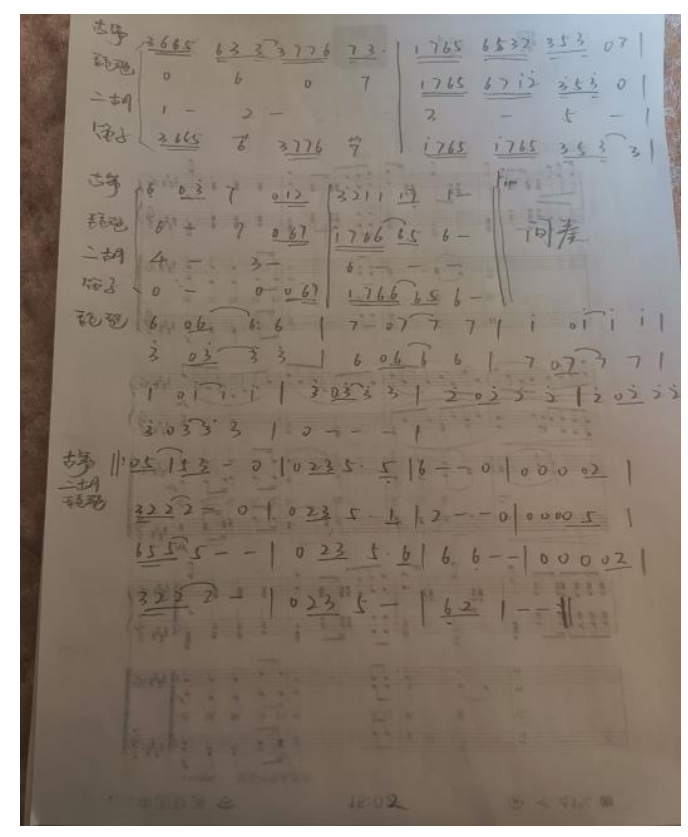

金蛇 狂舞

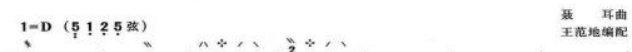

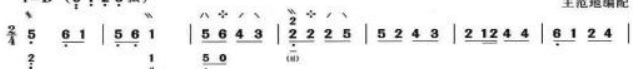
常

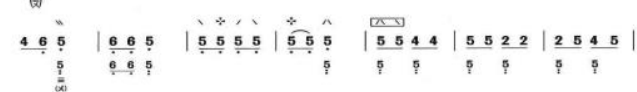

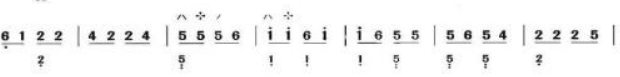
$5243|21244| 6124|465| 665|5656| 545 \mid$

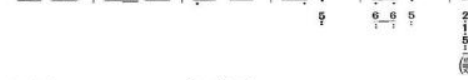

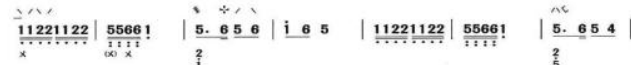

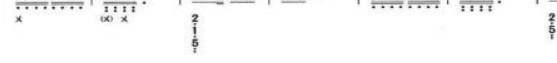

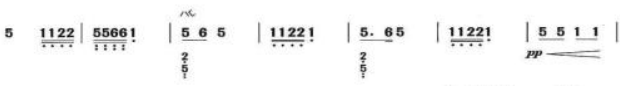
$5511|5515| 1515|5 \quad 5 \quad| 5 \quad 5\left|\frac{5.555}{555}\right|$

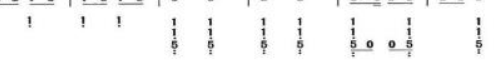

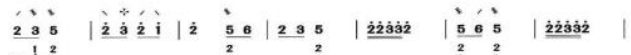

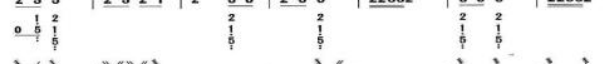

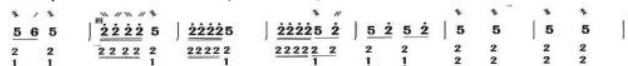

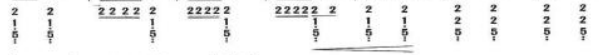

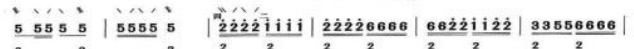

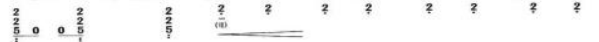

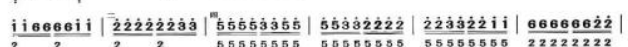

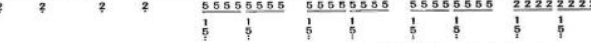

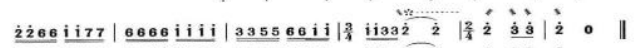

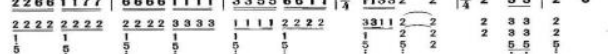
乐曲详船:

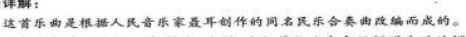

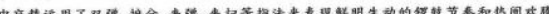

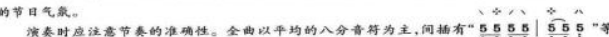

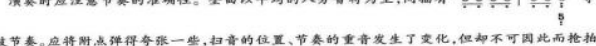

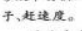

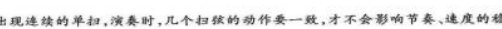
the.

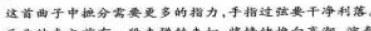

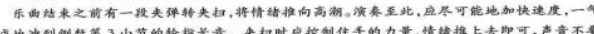
太然。 


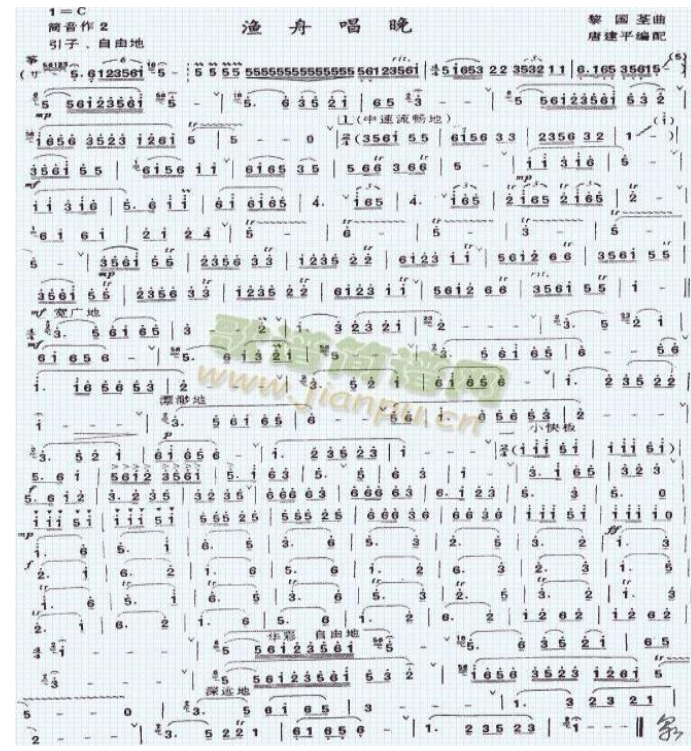

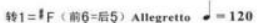

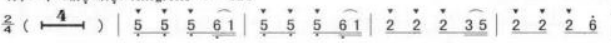

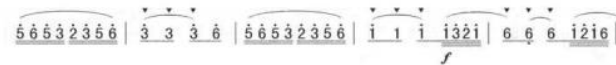

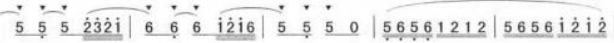

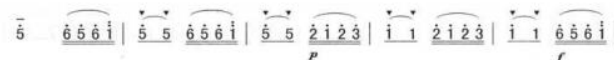

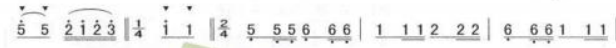

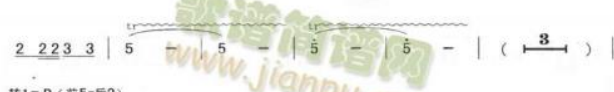

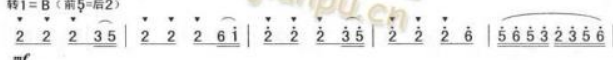

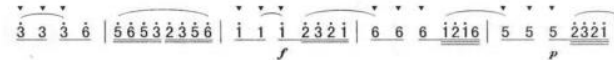

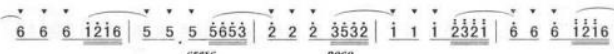

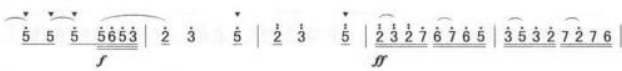

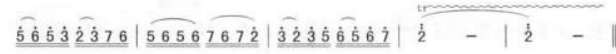

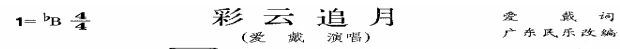

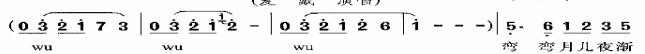

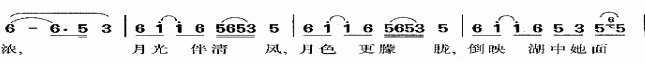

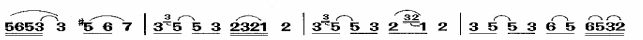

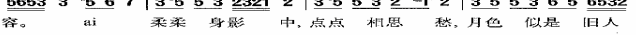

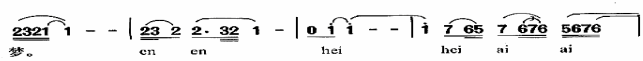

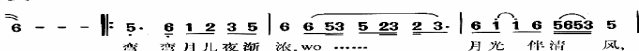

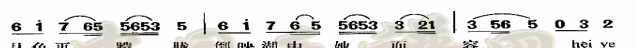

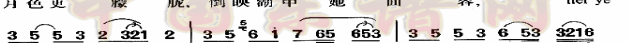

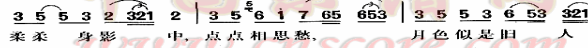

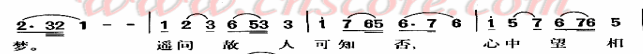
10. 23566535

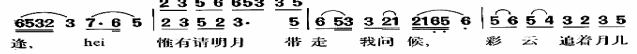

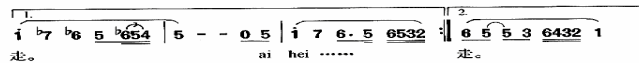
走。

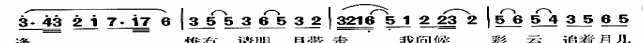

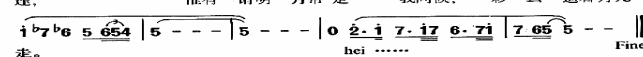

梁 祝

$1=E \frac{4}{4}$
Lago

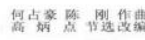

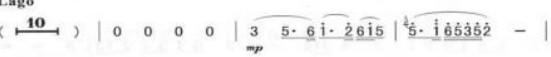

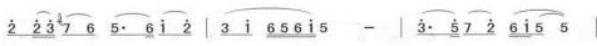

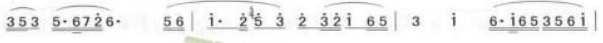
5. 0000 .

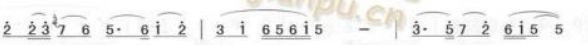

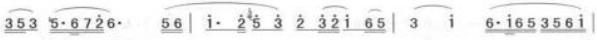

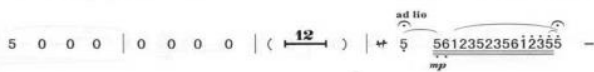

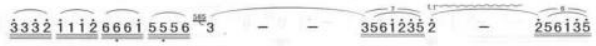

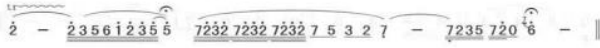

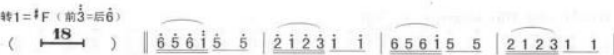
$566566|56656-15-| 5-15-1$

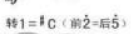

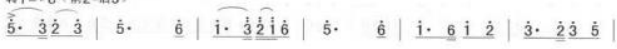

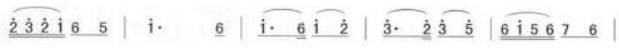

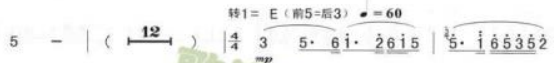
2 2⿺辶万

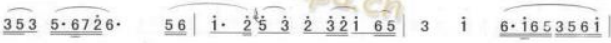

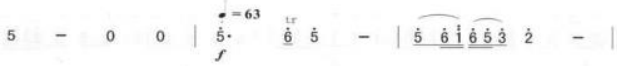

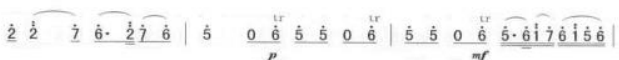

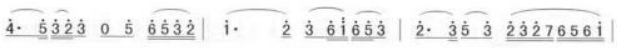

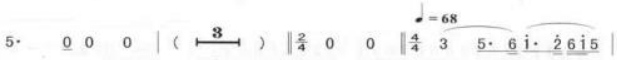
$1=0 \frac{2}{4} \quad$ 䒚䒚吕 轻盈优美、有活力地 小快板 $=92$ 千踏弱

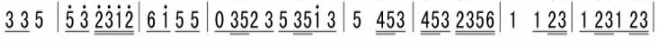

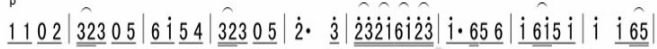

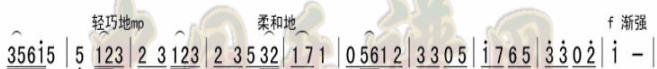
的渐强

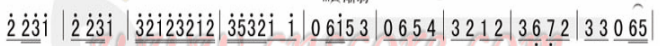

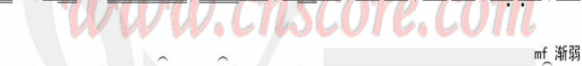

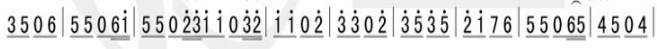

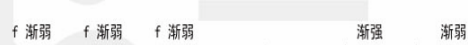

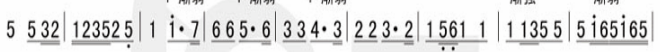

$\mathrm{f}$ 溯强

$\underline{3232112}|\underline{3.235}| \underline{67} \underline{\underline{i 232} 2 \mid}|i \quad i:| \quad$ 阿笑在线: http://ahxiao, 126. con 


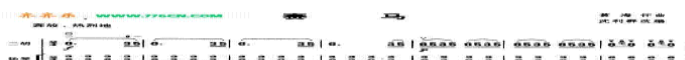

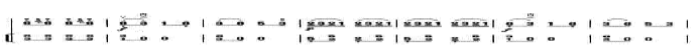

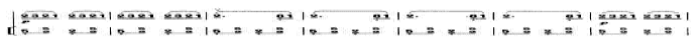
t|

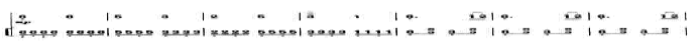

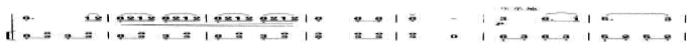

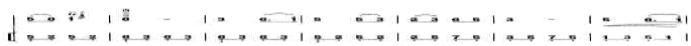

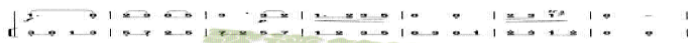

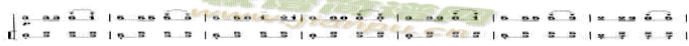

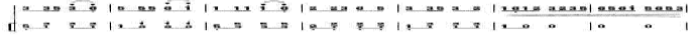
d

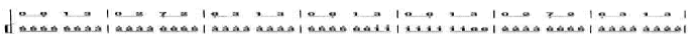

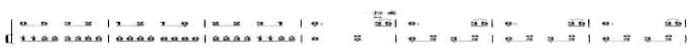
to: = . t

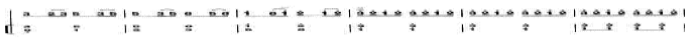

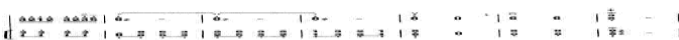

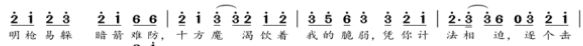

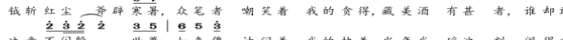

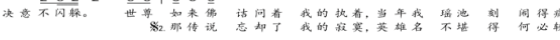
这.

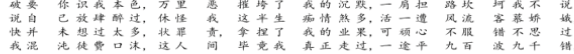

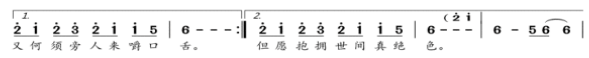

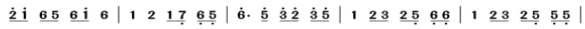

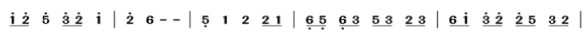

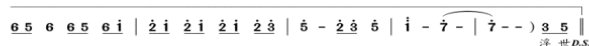

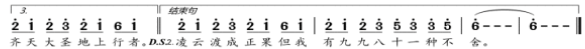

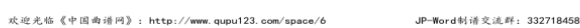

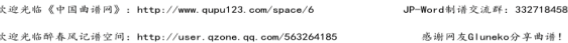

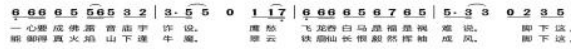

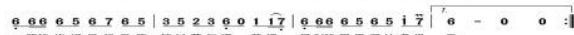

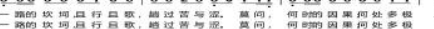

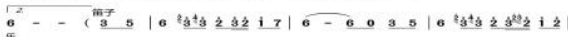

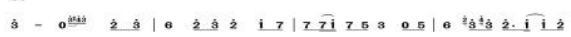

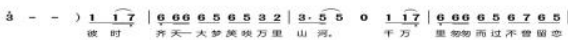
5. $330235|668658765| 352360177 \mid 6866565 i 7$

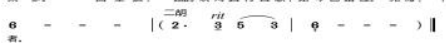

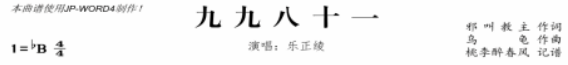

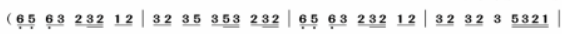
$65 \underline{63} \underline{232} \underline{12}|\underline{32} \underline{35} \underline{353} \underline{232}| \underline{65} \underline{63} \underline{232} \underline{12}|\underline{65} 656-6-| 6---\mid$

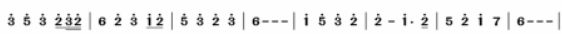

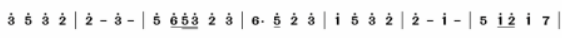

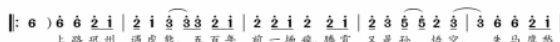

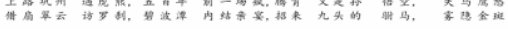

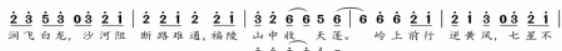

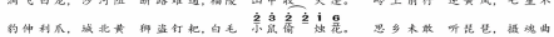

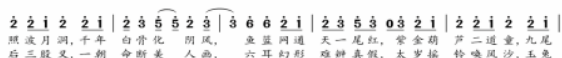

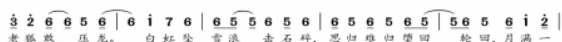

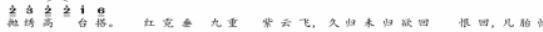

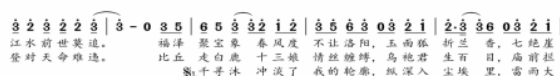

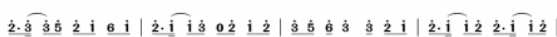

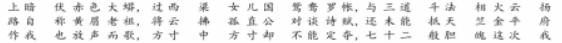

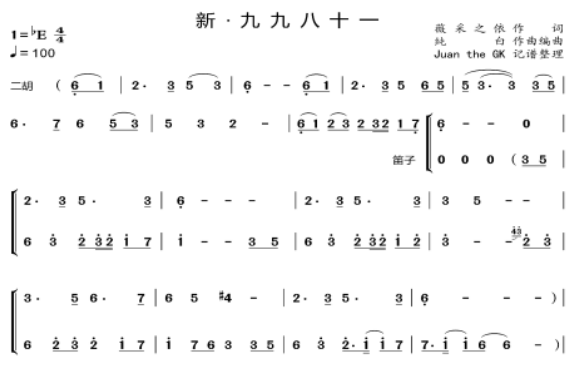
|l: $111161220|111161220| 777712171 \mid \widehat{23} \overparen{232} 150$

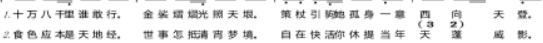
$111161220|111161220| 777712171|3.22055220|$

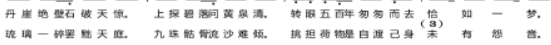

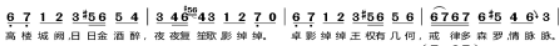

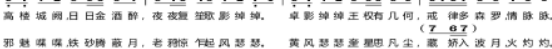

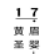
$6712345664|346431270| 671235656 \mid 678765567$

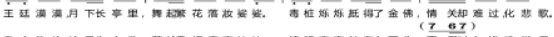

